\title{
A systematic framework for the assessment of sustainable hydropower potential in a river basin - The case of the upper Indus
}

\author{
Sanita Dhaubanjar a,b,*, Arthur F. Lutz ${ }^{\mathrm{b}}$, David E.H.J. Gernaat ${ }^{\mathrm{c}}$, Santosh Nepal ${ }^{\mathrm{a}}$, Wouter Smolenaars ${ }^{\mathrm{d}}$, \\ Saurav Pradhananga ${ }^{\mathrm{a}}$, Hester Biemans ${ }^{\mathrm{d}}$, Fulco Ludwig ${ }^{\mathrm{d}}$, Arun B. Shrestha ${ }^{\mathrm{a}}$, Walter W. Immerzeel $^{\mathrm{b}}$ \\ a International Center for Integrated Mountain Development (ICIMOD), Lalitpur 44700, Nepal \\ b Faculty of Geosciences, Universiteit Utrecht, Utrecht 3584 CB, Netherlands \\ c PBL Netherlands Environmental Assessment Agency, The Hague 2500 GH, Netherlands \\ ${ }^{\mathrm{d}}$ Wageningen University \& Research, Droevendaalsesteeg 4, 6708 PB Wageningen, Netherlands
}

\section{H I G H L I G H T S}

- We present a systematic framework to assess sustainable hydropower potential.

- The framework assesses theoretical, technical, economic, and sustainable potential.

- It combines 30 datasets to represent natural, legal, disaster and social constraints.

- Including these constraints in early assessments can improve hydropower decisions

- The framework helps balance SDG7 (energy) with the linked SDGs 2 \& 6 (food, water).

\section{A R T I C L E I N F O}

\section{Article history:}

Received 14 January 2021

Received in revised form 9 April 2021

Accepted 10 April 2021

Available online 16 April 2021

Editor: A.P. Dimr

\section{Keywords:}

Hydropower development

Sustainability

Sustainable development goals

Hydropower siting

Hydropower sizing

Hydropower potential

\section{G R A P H I C A L A B S T R A C T}

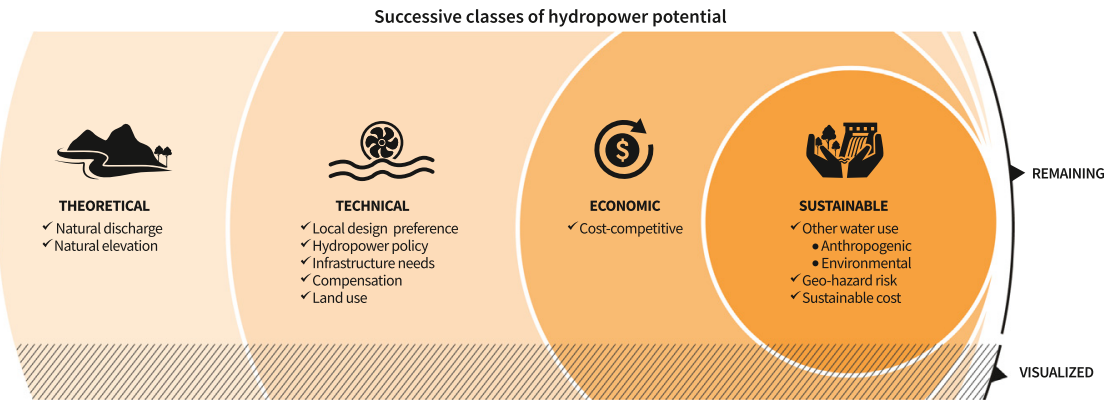

\begin{abstract}
A B S T R A C T
Siloed-approaches may fuel the misguided development of hydropower and subsequent target-setting under the sustainable development goals (SDGs). While hydropower development in the Indus basin is vital to ensure energy security (SDG7), it needs to be balanced with water use for fulfilling food (SDG2) and water (SDG6) security. Existing methods to estimate hydropower potential generally focus on: only one class of potential, a methodological advance for either of hydropower siting, sizing, or costing of one site, or the ranking of a portfolio of projects. A majority of them fall short in addressing sustainability. Hence, we develop a systematic framework for the basin-scale assessment of the sustainable hydropower potential by integrating considerations of the waterenergy-food nexus, disaster risk, climate change, environmental protection, and socio-economic preferences. Considering the case of the upper Indus, the framework is developed by combining advances in literature, insights from local hydropower practitioners and over 30 datasets to represent real-life challenges to sustainable hydropower development, while distinguishing between small and large plants for two run-of-river plant configurations. The framework first addresses theoretical potential and successively constrains this further by stepwise inclusion of technical, economical, and sustainability criteria to obtain the sustainable exploitable hydropower potential. We conclude that sustainable hydropower potential in complex basins such as the Indus goes far beyond the hydrological boundary conditions. Our framework enables the careful inclusion of factors beyond the
\end{abstract}

\footnotetext{
* Corresponding author at: International Center for Integrated Mountain Development (ICIMOD), Lalitpur 44700, Nepal.

E-mail addresses: sanita.dhaubanjar@icimod.org (S. Dhaubanjar), a.f.lutz@uu.nl (A.F. Lutz), david.gernaat@pbl.nl (D.E.H.J. Gernaat), Santosh.Nepal@icimod.org (S. Nepal), wouter.smolenaars@wur.nl (W. Smolenaars), saurav.pradhananga@icimod.org (S. Pradhananga), hester.biemans@wur.nl (H. Biemans), fulco.ludwig@wur.nl (F. Ludwig), Arun.Shrestha@icimod.org (A.B. Shrestha),W.W.Immerzeel@uu.nl (W.W. Immerzeel).
} 
status-quo technological and economic criterions to guide policymakers in hydropower development decisions in the Indus and beyond. Future work will implement the framework to quantify the different hydropower potential classes and explore adaptation pathways to balance SDG7 with the other interlinked SDGs in the Indus.

(C) 2021 The Authors. Published by Elsevier B.V. This is an open access article under the CC BY license (http:// creativecommons.org/licenses/by/4.0/).

\section{Introduction}

Achieving the Sustainable Development Goal (SDG) for energy ${ }^{1}$ in the transboundary Indus river basin (Fig. 1A), depends on hydropower development (Vaidya, 2013; GoP, 2014). However, goal-setting in the hydropower sector, a key linkage in the water-energy-food (WEF) nexus in the Indus, continues in its silo (Rasul et al., 2019; Hillman et al., 2020). The historical energy demand (2007-2016) in Pakistan averaged at $83 \mathrm{TWh} / \mathrm{yr}$, with over $24 \%$ of the demand curtailed due to insufficient supply (NTDC, 2019). To meet growing demands, a five-fold increase in hydropower capacity has been visualized in Pakistan alone (Siddiqi et al., 2012). Meanwhile the latest national plan outlines pathways to expand the share of hydropower from 29\% to 40\% in Pakistan's energy mix by 2040 (NTDC, 2019). These aspirational hydropower development targets rarely materialize because they are largely set for political clout (Khawaja, 2018), as governments flaunt hydropower as a solution to relieve the pressures of increasing demands, exacerbating power shortages, regional competition and global emphasis on renewables (Siddiqi et al., 2012; Hussain et al., 2019). Planned projects often face resistance at a later stage as they fail to consider the implications of spatio-temporal dependencies and sectorial trade-offs across the WEF nexus for the realization of hydropower (Rasul et al., 2019), and vice versa (Pittock et al., 2016; Fuso Nerini et al., 2018). For instance, hydropower expansion plans in north Indian part of the Indus are raising concerns for downstream water availability for humans and the environment in Pakistan (Kalair et al., 2019; Abas et al., 2019).

Poor hydropower planning often stems from the limitations of the knowledgebase on potential hydropower sites used for decisionmaking. At present, hydropower expansions in the Indus basin countries are guided primarily by the portfolio of potential sites shortlisted by their government agencies (CEA, 2018; Hussain et al., 2019). Even though legal provisions allow other stakeholders to identify sites, it remains rare in practice (Dhaubanjar and Mufti, 2020) because basinscale assessments can be resource-intensive (Müller et al., 2016). The latest national reports in Pakistan aggregate provincial estimates of hydropower potential at over 59,796 MW, $11 \%$ of which is realized (PPIB, 2011; WAPDA, 2012). Similarly, a 1987 study valued the potential in the Indian part of the Indus at 33,832 MW, of which $45 \%$ is existing (CEA, 2019). However, neither reports clarify the method used for identification of potential hydropower sites and refer to dated studies. Siddiqi et al. (2012) scrutinized over 800 potential sites from five national reports for Pakistan and found incomplete details for $60 \%$ of the projects and discrepancy across sources. While national hydropower databases lack transparency, consistency, completeness, and georeferencing, global databases only cover existing large hydropower plants with limited validation for the Indus (Lehner et al., 2011; FAO, 2014; Zarfl et al., 2015; Byers et al., 2019).

To improve hydropower development decisions, there is need for a comprehensive framework to assess the full range of hydropower potential by considering economic and non-economic factors equally, based on objective information. In their analysis of past hydropower development, the World Commission on Dams (WCD, 2000) found that a status quo bias plagues hydropower decisions (Samuelson and Zeckhauser, 1988), whereby projects that passed initial financial feasibility checks were more likely to be realized in spite of other issues, especially if they gained political momentum. The current hydropower potential estimation process in the Indus reinforces such status quo

\footnotetext{
${ }^{1}$ Energy refers to electrical energy throughout this study, unless otherwise specified.
}

bias in two folds. First, the current hydropower portfolios by national governments are myopic focusing on limited techno-economic criterion; these portfolios propagate such biases into hydropower decision-making as they form the basis of national hydropower planning exercises (Mirjat et al., 2017; CEA, 2018; NTDC, 2019). Second, considerations for social and environmental factors are legally required only once a project has passed the planning phase. Hence, poorly shortlisted projects may pick up momentum by passing economic criteria well before other concerns are identified (Afridi et al., 2014). In hindsight, it is worthwhile to place more attention to the first potential estimation exercises shortlisting these projects.

Many studies explore hydropower potential at global, regional (Lehner et al., 2005), national (Lee et al., 2007; Kao et al., 2014), subnational (Ramachandra and Shruthi, 2007; Cyr et al., 2011), basin (Cuya et al., 2013; Operacz, 2017; Garegnani et al., 2018), and individual project (Ray et al., 2018) scales. The complexities in the methods employed by these studies vary with scale and target specific project sizes. A majority of the larger scale studies focus narrowly on theoretical potential (Lehner et al., 2005; Pokhrel et al., 2008; Roach et al., 2015; Hoes et al., 2017). Gernaat et al. (2017) perform a rigorous global technical and economic analysis focusing on large plants. Studies covering medium to small-sized areas use GIS tools at finer resolution to obtain site-specific parameters to evaluate the economic potential for small hydropower plants (SHP) and highlight the need for customized costing and siting methods for these (Mishra et al., 2011; Müller et al., 2016; Garegnani et al., 2018; Moiz et al., 2018). Technical and economic considerations govern the majority of these hydropower potential estimation methods. Non-economic factors are generally accounted for in a follow up ranking of the generated portfolio of projects (Rojanamon et al., 2009; Annandale, 2014; JICA and NEA, 2014); or even later in the detailed designing of individual projects (Basso and Botter, 2012; IHA, 2017; Ray et al., 2018). Inclusion of these latter factors into the prior potential estimation exercise itself can prevent status quo biases. Integrating the strengths of the dispersed methods in literature into a single consistent framework can support the identification of a more judicious hydropower portfolio not skewed towards specific sizes or dominated by economic considerations.

Especially in the Indus, hydropower development cuts across multiple SDGs. Thus, to prevent conflicts in SDG target-setting, evaluation of the impacts on interlinked SDGs is important during the identification of hydropower potential. First, in line with SDG 6.5.1 on integrated management of water resources, considering the WEF nexus is imperative because water resources utilized by hydropower is at the heart of achieving water (SDG2), food (SDG6) and energy (SDG7) security (Rasul, 2016). The Indus basin, shared by Afghanistan (6\%), China (8\%), India (39\%) and Pakistan (46\%), is among the most waterstressed basins in the world (Gassert et al., 2013; Biemans et al., 2019). By 2080, water and energy security requirements here are projected to increase two to three-folds while food security requirements may double in comparison to 2015 (Fig. 1B). Hence, hydropower planning needs to consider changes in water abstraction to fulfil SDG2 and SDG6. Alternatively, hydropower expansion can affect water and areas available for food production under SDG2, aquatic biodiversity under SDG14 and terrestrial biodiversity under SDG15. Current surface water availability is also projected to shift in magnitude and occurrence with climate change (Lutz et al., 2016; Lutz et al., 2019; Wijngaard et al., 2018). Similarly, sustainability of hydropower infrastructures under geo-hazard risks should also be considered even in preliminary assessments for a hazard prone region like the Indus (Schwanghart et al., 


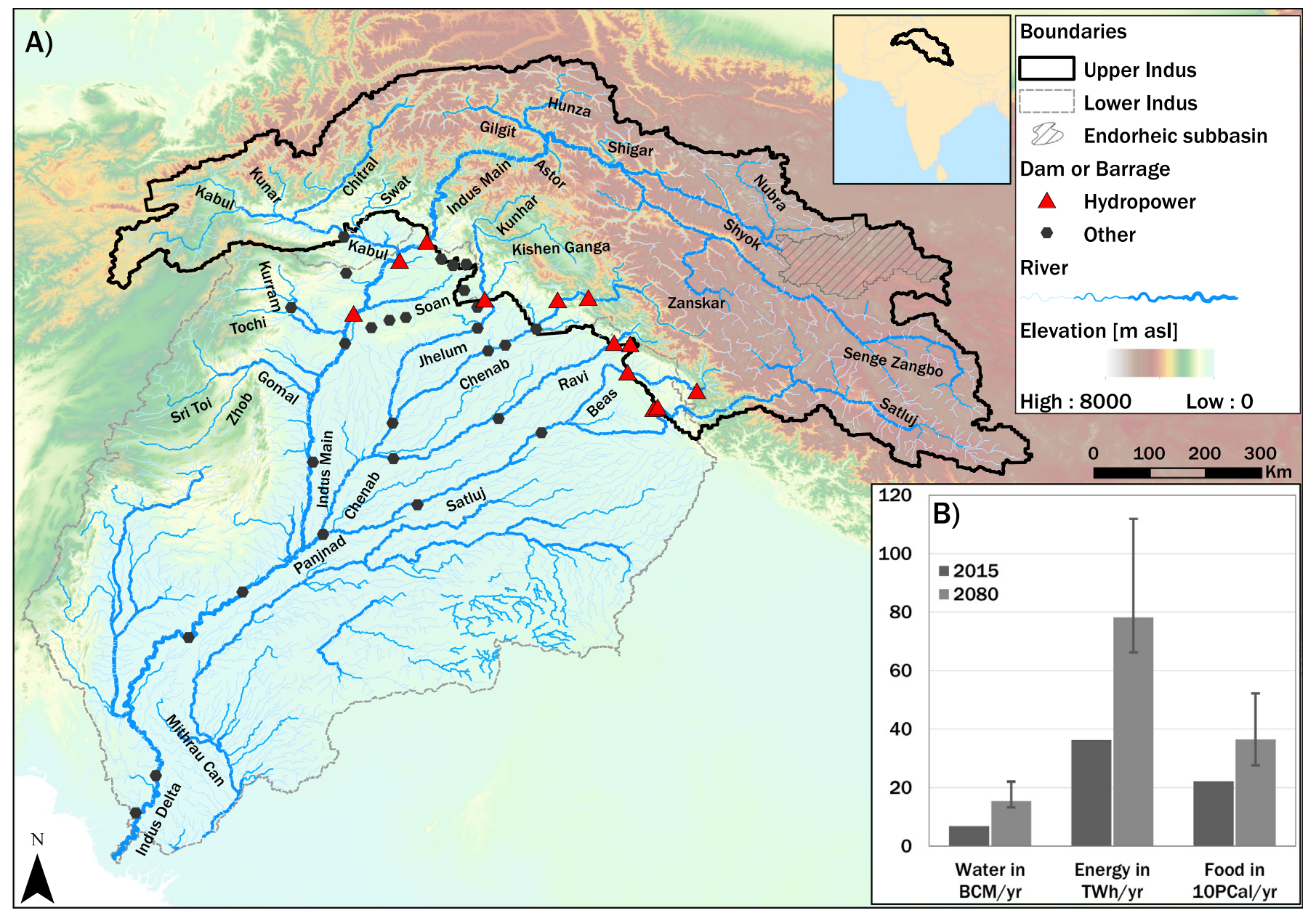

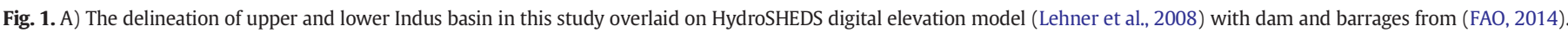

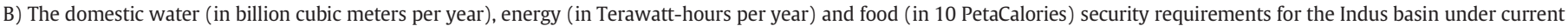
and future scenarios from (Smolenaars et al., 2020).

2018). These considerations for climate and geo-hazard resilience (GFDRR, 2017) align with the requirements of SDG13 (climate action) and SDG9 (sustainable infrastructures) respectively. Consequently, a hydropower potential estimation framework that accommodates the WEF nexus and represents these interlinked SDGs at the river basin scale can improve hydropower development decisions.

We hypothesize that current hydropower potential estimates focus narrowly on technical and economical consideration and a holistic framework is necessary to capture the many diverse constraints that should be considered for the sustainable development of hydropower. The scientific aim of this study is to develop such a framework in the context of the Indus basin that systematically incorporates theoretical, technical, economical and sustainability constraints to assess hydropower potential. The Indus is unique as its high theoretical potential for hydropower converges with transboundary water issues, rapid socio-economic changes, competing water demands, high susceptibility to hazards, and a vulnerable landscape. With the conceptualization of four hydropower potential classes and a synthesis of existing approaches, we develop a framework to make four notable improvements. First, we selectively integrate the scattered developments in literature into a single framework that incorporates multiple factors and SDGs associated with hydropower development. Second, we engage with stakeholders to identify and incorporate local considerations for hydropower design. Third, we include novel datasets to parameterize real world constraints into a quantitative model. Finally, by combining these three factors this paper provides the first framework that defines sustainable hydropower potential at the basin scale, considering two run-of-river (RoR) hydropower configurations. We focus our analysis on the upper Indus as global estimates show that over $80 \%$ of the hydropower potential in the Indus is located in the upper part (Gernaat et al., 2017; Hoes et al., 2017).

\section{Classification of hydropower potential}

While hydropower is a mature technology (IRENA, 2012), the lack of standardized definitions and estimation methods means that studies differ methodologically. To systematically explore hydropower potential in a basin, we decompose hydropower potential into four successive classes comprising a collective whole (Fig. 2). First, theoretical potential, also referred to as gross, full, or total theoretical potential, represents the energy that can be physically generated within the natural limits of the basin assuming that all available head and runoff is utilized for hydropower generation. However, the ability to realize the theoretical potential depends on the limits of existing engineering technologies; this second class is termed technical potential. Thirdly, only a portion of the technical potential will be economically viable and this is termed the economic potential. Even economic potential may not be fully realizable due to other non-technical and non-economic factors that link hydropower with other SDGs. Hence, we propose a new fourth class of sustainable exploitable potential that represents a sustainably achievable potential accounting for known hazard risks, anthropogenic limitations and environmental constraints to sustainability. Besides these, we define the visualized potential comprising of hydropower projects that are operational in 2020 (Existing 2020) or set to start 


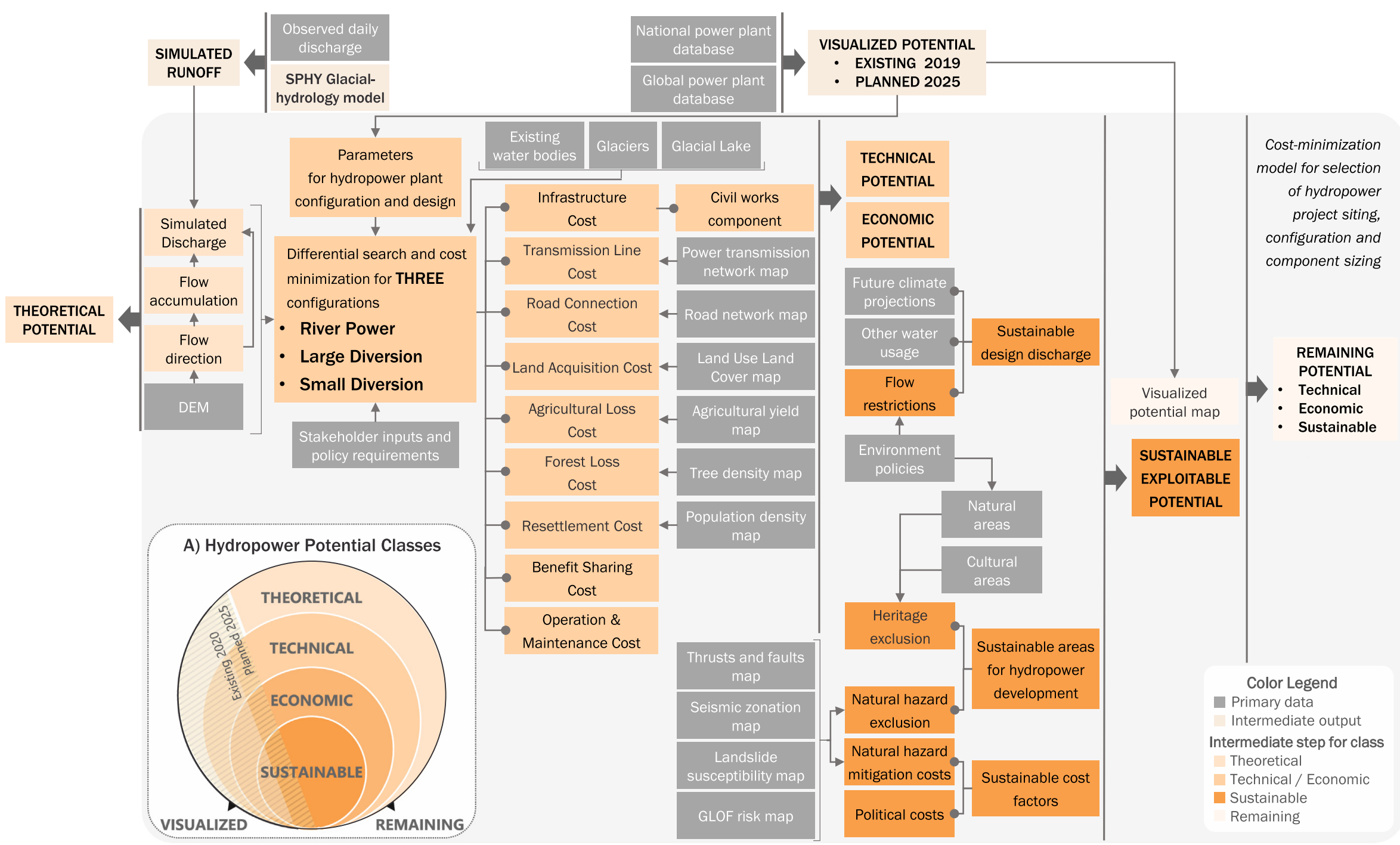

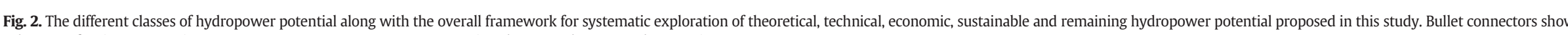
sub-parts of a given processing step. Arrow connectors represent connections between datasets and processing step. 
construction by 2025 (Planned 2025). Excluding the visualized potential from the previous classes provides the remaining potential.

\section{The systematic framework}

Potential estimation exercises (reviewed in Table 1) start by dividing the domain into smaller analysis units - either grid cells, river segments or subbasins. For each unit, the hydropower potential ( $\mathbf{P}$ in $\mathrm{Wh} / \mathrm{yr}$ ) is estimated using the available flow $\left(\mathbf{Q}\right.$ in $\left.\mathrm{m}^{3} / \mathrm{s}\right)$ and head difference $(\mathbf{H}$ in m) as follows:

$$
\mathbf{P}=\eta \rho g H Q t
$$

where $\eta$ is system efficiency (in \%), $\rho$ is the density of water (in $\mathrm{kg} / \mathrm{m}^{3}$ ), gis the gravitational acceleration $\left(9.8 \mathrm{~m} / \mathrm{s}^{2}\right)$ and $\mathbf{t}$ is annual hours of operation ( $h / y r)$. To evaluate the various classes of hydropower potential, we add increasing levels of complexity in the application of this equation, incorporating over 30 diverse datasets (Supplement B) to represent the constraints to hydropower development in the upper Indus (Fig. 2). Our assessment focuses on run-of-river plants that rely on the natural flow and head drop along a river. We exclude storage power plants that rely on the flux and head of water stored in a reservoir (IRENA, 2012), as storage plants can have significant environmental and social impacts that cannot be easily generalized (WCD, 2000). Additionally, the development of storage projects in the upper Indus remains controversial under the Indus water treaty (The World Bank, 2018).

\subsection{Theoretical potential}

\subsubsection{Existing approaches}

Theoretical potential estimation methods in literature (Table $1 \mathrm{~A}$ and B) vary in the application of the physical equation (Eq. (1)) with regard to the analysis resolution, the choice of head difference $(H)$ and the choice of flow (Q) input. As finer topographical and hydrological data became available over time, studies considered finer analysis units (grid cells or river segments). Selection of the analysis unit is also made based on basin topography, goals of analysis and computation time (Kusre et al., 2010; Cuya et al., 2013; Garegnani et al., 2018). Coarse analysis over large study areas generally focus on larger hydropower plants, using additional thresholds on $\mathrm{H}, \mathrm{Q}$ or $\mathrm{P}$ to limit computation resources to plants of interest (Fekete et al., 2010; Labriet et al., 2015; Hoes et al., 2017). Conversely, studies exploring SHP potential use finer river segments to target the high head locations over smaller study areas. For instance, studies in the Indus used $5 \mathrm{~km}$ (Vinca et al., 2019) or $25 \mathrm{~km}$ (Gernaat et al., 2017) segments to focus on large hydropower plants, while $0.1 \mathrm{~km}$ (Cuya et al., 2013; Garegnani et al., 2018) or $0.5 \mathrm{~km}$ (Khan, 2018; Moiz et al., 2018) segments were used for SHP. Alternatively, Operacz (2017) split the river at points where the flow changed by $1 \mathrm{~m}^{3} / \mathrm{s}$.

For selecting head difference, the earliest gridded assessments take $\mathrm{H}$ as either the grid elevation assuming the cell drains to the sea (Lehner et al., 2005; Pokhrel et al., 2008; Zhou et al., 2015) using Digital Elevation Models (DEMs) derived from remote-sensing products. This is generally considered a highly theoretical value which disregards that hydropower can only be generated along the river and not in individual cells (Lehner et al., 2005). More recently, the difference in head across cascading cells is used (Labriet et al., 2015; Hoes et al., 2017). Zhou et al. (2015) propose that for methodological consistency theoretical potential studies should use grid elevation, while technical potential studies should use head differences across cascading cells. Pokhrel et al. (2008) find that using elevation or head difference provides comparable estimates for coarse global analysis. However, similar to Lehner et al. (2005), they suggest using the latter for accurate analysis at finer scales that better incorporates the heterogeneity in elevation and discharge. Indeed, studies focusing on finer analysis for smaller scale plants, use head difference along the segment (Kusre et al., 2010;
Pandey et al., 2015; Moiz et al., 2018) or across its drainage area as more realistic (Cuya et al., 2013; de Souza et al., 2017).

For representing flow, four approaches are identified. Coarser global or regional analysis commonly use simulated runoff generated by hydrological models or by simpler water balance based on precipitation and evapotranspiration data (Fekete et al., 2010; Labriet et al., 2015). These gridded assessments used runoff-weighted elevation to obtain theoretical potential. Finer scale analysis need higher resolution discharge which is obtained by scaling simulated or observed discharge at select locations to generate discharge at other points in the same basin (Khan, 2018). Alternatively, some studies downscale runoff generated by a coarse models using higher resolution flow direction and accumulation maps to simulate gridded discharge at higher resolution (Gernaat et al., 2017; Hoes et al., 2017; Vinca et al., 2019).

Another important point to consider in finer scale analysis is the location of extraction of discharge - either at the segment outlet (Punys et al., 2011; de Souza et al., 2017), the segment inlet (Gernaat et al., 2017; Moiz et al., 2018), or across the segment length or drainage area (Cuya et al., 2013). de Souza et al. (2017) mathematically derive that using outlet discharge provides the maximum possible estimate for theoretical potential, but only $50 \%$ of this maximum can be realized by even the most intensive exploitation using cascading dams (de Souza et al., 2017). Cuya et al. (2013) corroborate that theoretical potential estimated using river segment discharge is more realistic, with values $45 \%$ lower than that estimated using outlet discharge, and closer to the estimates for technical and economic potential.

\subsubsection{Proposed approach}

The variations across literature show that the choice of $\mathrm{H}$ and $\mathrm{Q}$ made in a study can lead to a wide range of theoretical potential values. A value that represents the upper limit to what is practically achievable would be most useful in hydropower decision making. Practitioners can better select hydropower sites using results from high-resolution studies that identify specific river stretches in a basin that have high potential than from coarser analysis that look at absolute gravitational potential possessed by each unit of water at a specified elevation. Hence, we apply the practically useful theoretical potential estimation method in our framework. As literature suggest, for a high-resolution analysis of a topographically heterogeneous basin like the upper Indus, using elevation difference across river segments inlet/outlet ( $\left.\mathbf{Z}_{\text {inlet }}, \mathbf{Z}_{\text {outlet }}\right)$ is best. For flow, using discharge at the segment inlet ( $\mathbf{Q}_{\text {inlet }}$ ) aligns with practical implementation of run-of-river hydropower than methods considering discharge over the segment or at the outlet. Thus, we propose the discharge-weighted head difference in Eq. (2) as the theoretical upper limit for each river segment, assuming run-of-river configuration, $100 \%$ efficiency in power production and 24-hour operation.

$$
P_{\text {theoretical }}=\rho g\left(Z_{\text {inlet }}-Z_{\text {outlet }}\right) * Q_{\text {inlet }} * 8760 h / y r
$$

For obtaining elevation values, the 15" HydroSHEDs global DEM data (Lehner et al., 2013) is re-gridded to $500 \mathrm{~m}$. Discharge is obtained using simulated runoff from a state-of-the-art cryospheric-hydrological model for the upper Indus developed by (Khanal et al., 2020), based on the fully distributed Spatial Processes In Hydrology (SPHY) model (Terink et al., 2015). The SPHY model, set up at $5 \mathrm{~km}$ spatial resolution, uses ERA5 reanalysis climate data (Hersbach et al., 2020) for meteorological inputs and is calibrated at two discharge stations. Khanal et al. (2020) demonstrate that their three-step modeling strategy to explicitly calibrate the snow, glaciers, and rainfall-runoff processes improves the parameterization of glacier and snowmelt processes, which contribute over $60 \%$ of the water in the upper Indus (Lutz et al., 2014). Hence, we select Khanal et al. (2020)'s model as the best available simulator of high-resolution runoff for the data-scarce upper Indus basin. Khanal et al. (2020) show that their model with improved representation of snow and glacier dynamics captures the spatio-temporal variation 
Table 1

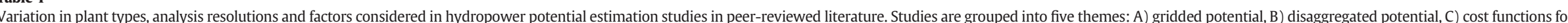

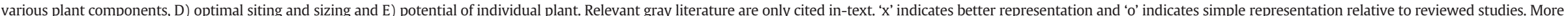
details on these studies, including design parameters and approaches, are provided in Supplement A.

\begin{tabular}{|c|c|c|c|c|c|c|c|c|c|c|c|c|c|c|c|c|c|}
\hline \multirow[t]{2}{*}{ Group } & \multirow[t]{2}{*}{ Source } & \multirow[t]{2}{*}{ Study Area } & \multirow[t]{2}{*}{ Plant type } & \multicolumn{3}{|c|}{ Resolution } & \multirow[t]{2}{*}{ Siting } & \multirow[t]{2}{*}{ Theoretical } & \multirow[t]{2}{*}{ Technical } & \multirow[t]{2}{*}{ Economic } & \multirow[t]{2}{*}{ Environment } & \multirow[t]{2}{*}{ Legal } & \multirow[t]{2}{*}{ Social } & \multirow{2}{*}{$\begin{array}{l}\text { Climate } \\
\text { change }\end{array}$} & \multirow[t]{2}{*}{ Geo-hazard } & \multirow{2}{*}{$\begin{array}{l}\text { Water } \\
\text { use }\end{array}$} & \multirow[t]{2}{*}{ Resettlement } \\
\hline & & & & Analysis unit & Topography & Hydrology & & & & & & & & & & & \\
\hline \multicolumn{2}{|c|}{ This study } & $\begin{array}{l}\text { Upper Indus, } \\
\text { Asia }\end{array}$ & $\begin{array}{l}\text { River power and } \\
\text { diversion RoR }\end{array}$ & $\begin{array}{l}500 \mathrm{~m} \text { grids, see } \\
\text { Table } 4\end{array}$ & $\begin{array}{l}3 " \text { and } 15^{\prime \prime} \\
\text { HydroSHEDS }\end{array}$ & $\begin{array}{l}5 \mathrm{~km} \text { local } \\
\text { model } \\
\text { simulation }\end{array}$ & $\mathrm{x}$ & $\mathrm{x}$ & $\mathrm{x}$ & $\mathrm{x}$ & $\mathrm{x}$ & $\mathrm{x}$ & & $\mathrm{x}$ & $\mathrm{x}$ & o & $\mathrm{x}$ \\
\hline \multirow[t]{5}{*}{ A } & $\begin{array}{l}\text { Lehner } \\
\text { et al. } \\
\text { (2005) }\end{array}$ & Europe & Gridded potential & $0.5^{\circ}$ grid cells & $\begin{array}{l}1 \mathrm{~km} \\
\text { HYDRO1k } \\
\text { DEM }\end{array}$ & $\begin{array}{l}0.5^{\circ} \text { global } \\
\text { model } \\
\text { simulation }\end{array}$ & & $\mathrm{x}$ & & & & & & & & o & \\
\hline & $\begin{array}{l}\text { Pokhrel } \\
\text { et al. } \\
\text { (2008) }\end{array}$ & World & Gridded potential & $0.5^{\circ}$ grid cells & $\begin{array}{l}0.5^{\circ} \text { HYDRO1k } \\
\text { DEM }\end{array}$ & $\begin{array}{l}0.5^{\circ} \text { global } \\
\text { model } \\
\text { simulation }\end{array}$ & & $\mathrm{x}$ & & & & & & & & & \\
\hline & $\begin{array}{l}\text { Labriet } \\
\text { et al. } \\
(2015)\end{array}$ & World & RoR and storage & $5^{\prime}$ grid cells & $\begin{array}{l}5^{\prime} \text { elevation } \\
\text { maps from } \\
\text { GAEZ }\end{array}$ & $\begin{array}{l}5^{\circ} \text { global } \\
\text { water } \\
\text { balance }\end{array}$ & & o & & & o & & & $\mathrm{x}$ & & & o \\
\hline & $\begin{array}{l}\text { Zhou et al. } \\
\text { (2015) }\end{array}$ & Global & Gridded potential & $0.5^{\circ}$ grid cells & $\begin{array}{l}0.5^{\circ} \\
\text { HydroSHEDS } \\
\text { DEM }\end{array}$ & $\begin{array}{l}0.5^{\circ} \text { global } \\
\text { water } \\
\text { balance }\end{array}$ & & o & $\mathrm{x}$ & $\mathrm{x}$ & o & & & & & & o \\
\hline & $\begin{array}{l}\text { Hoes et al. } \\
\text { (2017) }\end{array}$ & World & $\begin{array}{l}\text { Unspecified >1 } \\
\text { kW }\end{array}$ & 7.5" grid cells & $\begin{array}{l}\text { 7.5" } \\
\text { GMTED2010 }\end{array}$ & $\begin{array}{l}30^{\prime} \text { global } \\
\text { water } \\
\text { balance }\end{array}$ & & o & $\mathrm{x}$ & & & & & & & & \\
\hline \multirow[t]{5}{*}{ B } & $\begin{array}{l}\text { Fekete et al. } \\
\text { (2010) }\end{array}$ & Europe & $\begin{array}{l}\text { Storage with } \\
\text { capacity }>0.5 \\
\mathrm{~km}^{3}\end{array}$ & $\begin{array}{l}10,000 \mathrm{~km}^{2} \\
\text { subbasins }\end{array}$ & $\begin{array}{l}30^{\prime} \text { STN30p } \\
\text { v6.01 }\end{array}$ & $\begin{array}{l}30^{\prime} \text { global } \\
\text { water } \\
\text { balance }\end{array}$ & 0 & 0 & & & & o & & $\mathrm{x}$ & & & o \\
\hline & $\begin{array}{l}\text { Cuya et al. } \\
\text { (2013) }\end{array}$ & $\begin{array}{l}\text { La Plata, S. } \\
\text { America }\end{array}$ & River power RoR & $\begin{array}{l}\text { Subbasins and } 100 \\
\mathrm{~m} \text { river segments }\end{array}$ & $\begin{array}{l}900 \mathrm{~m} \text { local } \\
\text { DEM }\end{array}$ & $\begin{array}{l}\text { Observed } \\
\text { discharge } \\
\text { rescaling }\end{array}$ & & $\mathrm{x}$ & & & & & & & & & \\
\hline & $\begin{array}{l}\text { Butera and } \\
\text { Balestra } \\
(2015)\end{array}$ & $\begin{array}{l}\text { Piedmont, } \\
\text { Italy }\end{array}$ & Canal based RoR & $\begin{array}{l}\text { Existing links in } \\
\text { canal system }\end{array}$ & $\begin{array}{l}50 \mathrm{~m} \text { local } \\
\text { Digital Terrain } \\
\text { Model }\end{array}$ & $\begin{array}{l}\text { Observed } \\
\text { discharge }\end{array}$ & & o & & & & & & & & o & \\
\hline & $\begin{array}{l}\text { Operacz } \\
\text { (2017) }\end{array}$ & $\begin{array}{l}\text { Raba Basin, } \\
\text { Poland }\end{array}$ & Unspecified RoR & $\begin{array}{l}\text { Segments split } \\
\text { where change in } \\
\text { flow } \geq 1 \mathrm{~m}^{3} / \mathrm{s}\end{array}$ & Unspecified & $\begin{array}{l}\text { Observed } \\
\text { discharge } \\
\text { rescaling }\end{array}$ & & o & o & & o & o & & & & 0 & \\
\hline & $\begin{array}{l}\text { de Souza } \\
\text { et al. } \\
\text { (2017) }\end{array}$ & Brazil & Storage & $\begin{array}{l}\text { Basin and river } \\
\text { segments }\end{array}$ & Site data & Site data & & o & & & & & & & & & \\
\hline \multirow[t]{3}{*}{ c } & $\begin{array}{l}\text { Singal and } \\
\text { Saini } \\
\text { (2008) }\end{array}$ & India & $\begin{array}{l}\text { Canal based RoR } \\
\text { of } 1-5 \mathrm{MW}\end{array}$ & 70 projects & Site data & Site data & & & & $\mathrm{x}$ & & $\mathrm{x}$ & & & & & \\
\hline & $\begin{array}{l}\text { Aggidis } \\
\text { et al. } \\
\text { (2010) }\end{array}$ & $\begin{array}{l}\text { North West } \\
\text { UK }\end{array}$ & $\begin{array}{l}\text { Unspecified RoR } \\
\text { of 25-990 kW }\end{array}$ & 84 projects & Site data & Site data & & & & $\mathrm{x}$ & & & & & & & \\
\hline & $\begin{array}{l}\text { Ogayar and } \\
\text { Vidal } \\
\text { (2009) }\end{array}$ & Spain & $\begin{array}{l}\text { Unspecified RoR } \\
<2 \text { MW }\end{array}$ & $24+$ projects & Site data & Site data & & & & $\mathrm{x}$ & & & & & & & \\
\hline \multirow[t]{3}{*}{ D } & $\begin{array}{l}\text { Kaldellis } \\
\text { et al. } \\
\text { (2005) }\end{array}$ & Greece & $\begin{array}{l}\text { Small diversion } \\
\text { RoR }\end{array}$ & Individual project & Site data & Site data & & & & $\mathrm{x}$ & 0 & $\mathrm{x}$ & & & & o & \\
\hline & $\begin{array}{l}\text { Garegnani } \\
\text { et al. } \\
\text { (2018) }\end{array}$ & Norway & $\begin{array}{l}\text { Small diversion } \\
\text { RoR }<10 \text { MW }\end{array}$ & Individual project & Site data & Site data & & & & $\mathrm{x}$ & & & & & & & \\
\hline & $\begin{array}{l}\text { Basso and } \\
\text { Botter } \\
(2012)\end{array}$ & Italy & $\begin{array}{l}\text { Small diversion } \\
\text { RoR }\end{array}$ & Individual project & Site data & $\begin{array}{l}\text { Empirical } \\
\text { equation }\end{array}$ & & & $\mathrm{x}$ & 0 & 0 & & & & & & \\
\hline
\end{tabular}




\begin{tabular}{|c|c|c|c|c|c|c|c|c|c|c|c|c|c|c|c|c|}
\hline $\begin{array}{l}\text { Haddad } \\
\text { et al. } \\
\text { (2011) }\end{array}$ & Iran & $\begin{array}{l}\text { Small diversion } \\
\text { RoR }\end{array}$ & Individual project & Site data & Site data & & & & $\mathrm{x}$ & & & & & & & \\
\hline $\begin{array}{l}\text { Ray et al. } \\
\text { (2018) }\end{array}$ & Nepal & River power RoR & Individual project & Site data & $\begin{array}{l}\text { Local model } \\
\text { simulation }\end{array}$ & & & & $\mathrm{x}$ & & & & $\mathrm{x}$ & o & & \\
\hline $\begin{array}{l}\text { Kusre et al. } \\
\text { (2010) }\end{array}$ & $\begin{array}{l}\text { Umkhen river, } \\
\text { India }\end{array}$ & $\begin{array}{l}\text { Small diversion } \\
\text { RoR w head } \geq 10 \\
\mathrm{~m}\end{array}$ & $20 \mathrm{~m}$ grid cells & $\begin{array}{l}20 \mathrm{~m} \text { DEM for } \\
\text { site }\end{array}$ & $\begin{array}{l}\text { Local model } \\
\text { simulation }\end{array}$ & o & & 0 & & & & & & & & \\
\hline $\begin{array}{l}\text { Rojanamon } \\
\text { et al. } \\
\text { (2009) }\end{array}$ & $\begin{array}{l}\text { Nan river, } \\
\text { Thailand }\end{array}$ & $\begin{array}{l}\text { Small diversion } \\
\text { RoR 1-10 MW }\end{array}$ & $\begin{array}{l}\text { Unspecified grids } \\
\text { Search radius: } 5 \mathrm{~km}\end{array}$ & $\begin{array}{l}\text { DEM from } \\
\text { local } \\
\text { topography } \\
\text { map }\end{array}$ & $\begin{array}{l}\text { Observed } \\
\text { discharge } \\
\text { rescaling }\end{array}$ & o & & $\mathrm{x}$ & $\mathrm{x}$ & o & & $\mathrm{x}$ & & & & o \\
\hline $\begin{array}{l}\text { Yi et al. } \\
\text { (2010) }\end{array}$ & $\begin{array}{l}\text { Geum river, } \\
\text { Korea }\end{array}$ & $\begin{array}{l}\text { River power and } \\
\text { diversion RoR }\end{array}$ & $\begin{array}{l}30 \mathrm{~m} \text { grid cells } \\
\text { Search radius: } \\
0.1-1 \mathrm{~km}\end{array}$ & $\begin{array}{l}30 \mathrm{~m} \text { DEM for } \\
\text { site }\end{array}$ & Not used & 0 & & $\mathrm{x}$ & & 0 & & & & & & \\
\hline $\begin{array}{l}\text { Larentis } \\
\text { et al. } \\
\text { (2010) }\end{array}$ & $\begin{array}{l}\text { Taquari-Antas } \\
\text { river, Brazil }\end{array}$ & $\begin{array}{l}\text { River power and } \\
\text { diversion RoR } \\
\geq 10 \mathrm{~kW}\end{array}$ & $\begin{array}{l}450^{\circ} \mathrm{m} \text { river } \\
\text { segments } \\
\text { Search radius: } 1.8 \\
\mathrm{~km}\end{array}$ & 3" SRTM DEM & $\begin{array}{l}\text { Observed } \\
\text { discharge } \\
\text { rescaling }\end{array}$ & $\mathrm{x}$ & & 0 & & & & & & & o & \\
\hline $\begin{array}{l}\text { Pandey } \\
\text { et al. } \\
\text { (2015) }\end{array}$ & $\begin{array}{l}\text { Mat river, } \\
\text { India }\end{array}$ & $\begin{array}{l}\text { Small diversion } \\
\text { RoR w head } \geq 20 \\
\mathrm{~m}\end{array}$ & $\begin{array}{l}10 \mathrm{~m} \text { grid cells } \\
\text { Search radius: } 3 \mathrm{~km}\end{array}$ & $\begin{array}{l}10 \mathrm{~m} \text { DEM by } \\
\text { local agency }\end{array}$ & $\begin{array}{l}10 \mathrm{~m} \text { local } \\
\text { model } \\
\text { simulation }\end{array}$ & 0 & & $\mathrm{x}$ & & & & & & & & \\
\hline $\begin{array}{l}\text { Müller } \\
\text { et al. } \\
\text { (2016) }\end{array}$ & Nepal & $\begin{array}{l}\text { Small diversion } \\
\text { RoR }\end{array}$ & $\begin{array}{l}30 \mathrm{~m} \text { grid cells } \\
\text { Search radius: } 2 \mathrm{~km}\end{array}$ & $\begin{array}{l}30 \mathrm{~m} \text { ASTER } \\
\text { GDEM }\end{array}$ & $\begin{array}{l}\text { Local model } \\
\text { simulation }\end{array}$ & $\mathrm{x}$ & & & $\mathrm{x}$ & & & & & & & \\
\hline $\begin{array}{l}\text { Gernaat } \\
\text { et al. } \\
\text { (2017) }\end{array}$ & World & $\begin{array}{l}\text { Large river power } \\
\text { and diversion } \\
\text { RoR }\end{array}$ & $\begin{array}{l}25 \mathrm{~km} \text { river } \\
\text { segments } \\
\text { Search radius: } 20 \\
\mathrm{~km}\end{array}$ & $\begin{array}{l}3 " \text { and } 15 " \\
\text { HydroSHEDS }\end{array}$ & $\begin{array}{l}0.5^{\circ} \text { global } \\
\text { model } \\
\text { simulation }\end{array}$ & $\mathrm{x}$ & & $\mathrm{x}$ & $\mathrm{x}$ & $\mathrm{x}$ & & & 0 & 0 & 0 & $\mathrm{x}$ \\
\hline $\begin{array}{l}\text { Moiz et al. } \\
\text { (2018) }\end{array}$ & $\begin{array}{l}\text { Kunhar river, } \\
\text { Pakistan }\end{array}$ & $\begin{array}{l}\text { Small diversion } \\
\text { RoR of 2-25 MW }\end{array}$ & $\begin{array}{l}500 \mathrm{~m} \text { river } \\
\text { segments } \\
\text { Search radius: 2-5 } \\
\mathrm{km}\end{array}$ & $\begin{array}{l}30 \mathrm{~m} \text { SRTM } \\
\text { DEM }\end{array}$ & $\begin{array}{l}300 \mathrm{~m} \text { local } \\
\text { model } \\
\text { simulation }\end{array}$ & $\mathrm{x}$ & & 0 & & $\mathrm{x}$ & & & & & & \\
\hline $\begin{array}{l}\text { Khan } \\
\text { (2018) }\end{array}$ & $\begin{array}{l}\text { Kunhar river, } \\
\text { Pakistan }\end{array}$ & $\begin{array}{l}\text { Small diversion } \\
\text { RoR }\end{array}$ & $\begin{array}{l}500 \mathrm{~m} \text { river } \\
\text { segments }\end{array}$ & $\begin{array}{l}30 \mathrm{~m} \text { ASTER } \\
\text { DEM }\end{array}$ & $\begin{array}{l}\text { Observed } \\
\text { discharge } \\
\text { rescaling }\end{array}$ & o & & 0 & & & & & & & & \\
\hline $\begin{array}{l}\text { Garegnani } \\
\text { et al. } \\
\text { (2018) }\end{array}$ & $\begin{array}{l}\text { Piedmont } \\
\text { Region, Italy }\end{array}$ & $\begin{array}{l}\text { Small diversion } \\
\text { RoR }\end{array}$ & $\begin{array}{l}100 \mathrm{~m} \text { river } \\
\text { segments } \\
\text { Search radius: } \\
0.1-1 \mathrm{~km}\end{array}$ & Unspecified & $\begin{array}{l}\text { Empirical } \\
\text { equation }\end{array}$ & $\mathrm{x}$ & $\mathrm{x}$ & $\mathrm{x}$ & $\mathrm{x}$ & $\mathrm{x}$ & 0 & 0 & & & 0 & \\
\hline
\end{tabular}


more accurately. The simulated 40-year long-term monthly average runoffs from 1979 to 2018 is downscaled to $500 \mathrm{~m}$ discharge by a discharge routing algorithm whereby discharge in each cell is the sum of all runoff generated upstream using the $500 \mathrm{~m}$ flow direction and accumulation maps (Gernaat et al., 2017).

\subsection{Technical and economic potential}

\subsubsection{Existing approaches}

Hydropower technology comprises of civil engineering works and electro-mechanical equipment, both of which are well-developed and commercially implemented in diverse terrains (WCD, 2000; IRENA, 2012). Hence, the definitions of technical limitations to the realization of hydropower potential vary across literature. At minimum, the technical constraint is represented by lowering the system efficiency. Elsewhere, $\mathrm{Q}$ in Eq. (1) is replaced by the design flow based on hydropower design preferences (Table 1 ). Correspondingly, approaches to estimate flow duration curves and design flows are presented by many studies exploring technical and economic potential, as accuracy of discharge is a sensitive factor (Zhou et al., 2015). Some studies also apply minimum/maximum discharge, head or segment length to represent realistic component sizes allowed by engineering standards. For instance, discharge or drainage area thresholds are applied as turbines for low discharge are uncommon (Butera and Balestra, 2015). Penstock and diversion canals need to have construction-friendly slopes and lengths with acceptable friction losses (Müller et al., 2016; Gernaat et al., 2017; Garegnani et al., 2018). Increasingly, studies have used stakeholder inputs to define these thresholds and added other constraints to capture local design policies, practices and preferences (Rojanamon et al., 2009; Müller et al., 2016; Garegnani et al., 2018; Moiz et al., 2018).

Nearly three-quarters of the hydropower project cost is based on site-specific parameters (IRENA, 2012). Hence only a few adequate resolution studies evaluate economic potential; these generally target a subset of factors related to site-specific component sizing or costing (Mishra et al., 2011). In the reviewed studies (Table 1), project cost is either estimated simply as a lump sum value using simple power-law functions ( of H, Q or P) (Zhou et al., 2015), or more accurately by dimensioning individual components (Gernaat et al., 2017; Garegnani et al., 2018). While most studies limit themselves to the cost of civil works and electro-mechanical components, some include costs such as land acquisition, licensing, resettlement, project development and grid connection to account for all foreseeable costs. Further distinctions are made in the cost functions based on project sizes (Table 1C). Economic potential estimation methods can be grouped into three types, namely those focusing on the cost of past projects (Table 1C), optimizing performance to minimize cost of one plant (Table 1D), or the evaluation of economic viability of multiple sites in a basin (Table 1E). In the latter case, projects with an acceptable economic performance, evaluated based on indicators such as the net present value (Garegnani et al., 2018), initial rate of return (Rojanamon et al., 2009), cost-benefit ratio (Haddad et al., 2011), per unit production cost (Zhou et al., 2015; Gernaat et al., 2017) or demand fulfilment ratio (Müller et al., 2016), are aggregated into economic potential.

Considering the importance of site specificity in project costs, more recent SHP studies highlight the need to select sites to maximize potential (Table 1E). These demonstrate that using GIS-based siting algorithms to divide a river into optimal segments that harness the variation in discharge and head within the basin to maximize power production or reduce production costs are more realistic technically and economically than studies that divide the river into segments of equal length. The advantages of a sophisticated siting algorithm in the upper Indus is demonstrated by two studies exploring the potential of Kunhar sub-basin. Moiz et al. (2018)'s search algorithm can be attributed for identifying an optimal portfolio with 36 sites with $388 \mathrm{MW}$ of hydropower capacity, while Zaidi and Khan (2018)'s equal river segment approach suggest a combination of over 200 smaller sites to achieve the same capacity. Note, however, that the smaller $500 \mathrm{~m}$ river segment length considered by Zaidi and Khan (2018) results in an abundance of smaller sites compared to Moiz et al. (2018)'s river segment lengths varied between 2 and $5 \mathrm{~km}$. Garegnani et al. (2018) also point out such impact of analysis resolution on identified plant sizes.

In summary, the subjective representation of technical constraints, the breadth of sophisticated cost functions distinguishing small and large plants and the siting algorithm development individually capture separate aspects of estimating the technical and economic hydropower potential. An integration of these scattered efforts can provide a superior framework to consider all known constraints leveraging the latest evaluation methods. Gernaat et al. (2017) represent a promising effort in that direction, albeit limited to larger plants at the global scale. They combine hydropower siting, configuring and sizing into a single integrated cost-minimization model, which first optimally sizes plants at individual sites and then selects the optimal hydropower portfolio with the best combination of sites to minimize per unit cost of power production. Unlike other studies that separate the process of project siting and sizing (Müller et al., 2016; Garegnani et al., 2018), Gernaat et al. (2017)'s approach better represent the real life design process where project site, configuration and size are best selected simultaneously to fulfil design objectives (WCD, 2000; Yousuf, 2017).

Gernaat et al. (2017) consider two plant configurations at each site: the diversion plant (DP) and the river power plant (RP), with different functions used in sizing and costing of project components. Prior studies referring to run-of-river potential mainly consider the DP configuration, where an upstream diversion intake channels water into an off-stream powerhouse, after which water is returned to the river downstream (Table 1). However, run-of-river plants in South Asia can also have the RP configuration including a small dam and reservoir (Mahar and Asher, 2020) that allows for peaking hydropower operation and flood protection (SedAlp, 2015; IRENA, 2018). Since technology is rarely the bottleneck for hydropower, Gernaat et al. (2017) aggregate individual projects under technical or economic potential using financial cutoffs, namely a maximum cost of USD $0.50 / \mathrm{kWh}$ or USD $0.10 / \mathrm{kWh}$, respectively; these are globally cost-competitive thresholds for all energy sources and only hydropower in the last decade (IRENA, 2020).

\subsubsection{Proposed approach}

We take the state-of-the-art global modeling framework by Gernaat et al. (2017) as a starting point and enhance its representation of small hydropower plants and its suitability for the upper Indus. First, we improve the hydrological representation by replacing the global hydrology in Gernaat et al. (2017) with outputs of the high-resolution cryospherichydrological SPHY model developed and calibrated specifically for the upper Indus (see Section 3.1.2). We interviewed hydropower practitioners from Pakistan (listed in Supplement C), reviewed policy documents (WAPDA, 2002; NEPRA, 2005; 2009; 2018; PPIB, 2011; GoP, 2015), and studied the power market setup (Aziz and Ahmad, 2015; Mirjat et al., 2017; Khan, 2018; Hussain et al., 2019) to understand local policies, practices and preferences for hydropower design. Thereafter we explicitly include various Indus specific datasets to represent the many factor that affect hydropower design and feasibility assessment into the technical and economic potential estimation framework.

We engaged with hydropower practitioners from Pakistan using the Delphi approach (Hsu and Sandford, 2007) whereby we used multiple rounds of online engagements to generate consensus among experts on hydropower design practices and preferences in the upper Indus. First, keeping with the restrictions of coronavirus pandemic, we held semi-structured individual online interviews with hydropower developers working in the design and implementation of public, private and donor-funded hydropower projects in Pakistan, using the questionnaire presented in Supplement D. The questionnaire inquired about factors currently considered during project design, cost estimation, project performance evaluation and assessment of climate, geo hazard, environmental and other risks. The interviews were combined with review 
Table 2

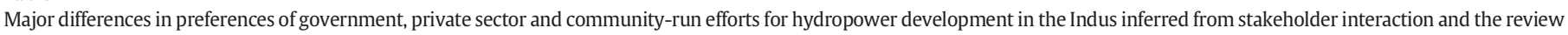
of power market structure and hydropower policy documents.

\begin{tabular}{|c|c|c|c|}
\hline & Government & Private sector & Provinces \& communities \\
\hline Funding & National or donor & Private investment & Bottoms up community effort w NGO or provincial funds \\
\hline $\begin{array}{l}\text { Motivation or optimization } \\
\text { criteria }\end{array}$ & $\begin{array}{l}\text { Maximize production for } \\
\text { given budget } \\
\text { Avoided cost of other } \\
\text { energy sources }\end{array}$ & Minimize cost of production & Maximize community benefits \\
\hline Size & Mega/Large & Large/Medium & Small/Micro/Mini/Pico \\
\hline Configuration & $\begin{array}{l}\text { River power plant or } \\
\text { Storage }\end{array}$ & Diversion plant & Diversion plant \\
\hline Siting & Mainstream of Indus & $\begin{array}{l}\text { Near existing roads and } \\
\text { transmission network }\end{array}$ & $\begin{array}{l}\text { - On smaller streams and tributaries } \\
\text { - Near settlements } \\
\text { - High head areas }\end{array}$ \\
\hline $\begin{array}{l}\text { Most expensive project } \\
\text { elements }\end{array}$ & $\begin{array}{l}\text { RCC dam } \\
\text { Underground } \\
\text { powerhouse }\end{array}$ & $\begin{array}{l}\text { De-sanding basin } \\
\text { Blasted tunneling } \\
\text { Underground powerhouse }\end{array}$ & Electro-mechanical, including local transmission cost \\
\hline $\begin{array}{l}\text { Qdesign ( } Q X X=\text { flow } \\
\text { exceeded } \mathrm{xx} \% \text { of the time) }\end{array}$ & $\begin{array}{l}\text { For major river: Q50 } \\
\text { For high-head projects } \\
\text { on tributaries: Q90. }\end{array}$ & $\begin{array}{l}\text { Plants are fully operational for } \\
\text { 3-4 months } ~ Q 25-Q 30\end{array}$ & $\begin{array}{l}\text { Typically, projects are sized to work year round } \\
\sim Q 80\end{array}$ \\
\hline $\begin{array}{c}\text { Land acquisition } \\
\text { management }\end{array}$ & \multicolumn{2}{|c|}{$\begin{array}{l}\text { Compensation based on assessed value of land classes } \\
\text { (barren, rural/urban, cultivated/uncultivated }\end{array}$} & Land contributed and cared for by community \\
\hline $\begin{array}{l}\text { Affected population } \\
\text { management }\end{array}$ & \multicolumn{2}{|c|}{$\begin{array}{l}\text { Entitlement matrix sets criteria for individual } \\
\text { compensation } \\
\text { Communal compensation addressed separately in mutual } \\
\text { agreements }\end{array}$} & Arranged by/within communities \\
\hline Grid connection & Not a bottleneck & Major bottleneck & Minor bottleneck if mini-grid needs to be setup \\
\hline Environmental management & \multicolumn{2}{|c|}{$\begin{array}{l}\text { - Exclusion of protected areas } \\
\text { - E-flow assessment and baseline studies conducted as } \\
\text { part of donor requirements } \\
\text { - Forest loss per tree basis }\end{array}$} & $\begin{array}{l}\text { For AKRSP, } 100 \mathrm{~m} \text { away from environmental or cultural heritages, freshwater or } \\
\text { marine wetlands and areas of significant natural vegetation }\end{array}$ \\
\hline
\end{tabular}

of power market structure and hydropower policies to develop an overview of the hydropower development modalities in Pakistan (Table 2). Thereafter, through iterative discussions with the same stakeholders, we translated these into quantitative modeling parameters and criterions (Table 3) for use in the technical and economic potential framework framework.

We found clear preferences in the Indus for hydropower project sizing and siting based on three groups of hydropower developers (Table 2). Firstly, according to the Power Policy in Pakistan, projects larger than $50 \mathrm{MW}$ are centrally managed while small projects $(<50$ $\mathrm{MW}$ ) are managed by provinces with simplified requirements for licensing and due diligence. The central government is focused on development of large storage based projects including RP projects, while DP projects are open to private developers (GoP, 2015). Secondly, private developers are generally interested in medium to large projects that are close to existing transmission and road networks providing commercial prospects for selling energy to the grid. Finally, provincial governments in the upper Indus are trying to attract private investors into small projects (GoGP and GoKP, 2016). Scattered communities across the upper Indus, residing mostly along the tributaries are interested in smaller medium to high head plants that can be built and managed through a bottom-up approach by themselves. Such community-run projects are largely off-grid and exempt from sub-national management (GoP, 2015). Furthermore, stakeholders clarified that the main rivers in the basin are reserved for large projects as these require high investments and strenuous due diligence processes.

Considering these preferences in the Indus, we propose a differentiation in methods for three plant categories: large RP, large DP and small DP. The large RP plants are considered of interest to government developers, while small DP ( $<50 \mathrm{MW}$ ) and large plants represent interests of provinces/communities and the private sector respectively. First, we separate the mainstreams from tributaries in the upper Indus by tracing up from the sub-basin outlets to the upstream cell with the highest discharge (Supplement E). Thereafter, we use Gernat et al. (2017)'s algorithm to search for larger RP and DP plants in the main stream and small DP plants in the tributaries with search parameters listed in (Table 3).
For evaluating costs for the three plants, we asked stakeholders to shortlist key components to include in the costing, and then identified suitable cost functions for these from literature (NVE, 2012a; b; Gernaat et al., 2017). As small plants have a shorter construction time, require lower formalities and engage locals for construction, many cost components are waived. The design parameters in Table 3 are selected based on stakeholder input, values in literature, policy requirements and the design documents for government-led Dasu hydropower project (DHP, 2019; 2020a) and community-led Madaklasht mini hydro power project (AKRSP, 2020) in the upper Indus. A provincial water use charge (GoP, 2015) levied on large projects is also applied. We additionally remove areas with glaciers (RGI Consortium, 2017), glacial lakes (Maharjan et al., 2018) and other surface water lakes (Messager et al., 2016) as technically inaccessible for hydropower (Fig. 3A).

Stakeholders highlighted three key bottlenecks to hydropower that we include in the framework: distances to nearest road, transmission line and settlements (Fig. 4A-C). As the majority of the upper Indus is remote, hydropower development will necessitate the construction of roads and expansion of existing transmission networks, which can significantly increase the costs (IRENA, 2012). We use the Global Roads Inventory Project (GRIP4) road dataset (Meijer et al., 2018) to account for the cost of road access for each project (Fig. 3B). The global GRIP4 dataset is updated using information from the OpenStreetMap (OSM) (OpenStreetMap, 2020), country-level road maps (Atlassian, 2018) and stakeholder input. From these, we distinguish highways or primary roads with paved surfaces as roads suitable to support hydropower construction.

For large projects, connection to the national grid is required and subsequently we account for distribution losses that reduce the transmission efficiency of on-grid systems (NEPRA, 2019). We extend a global transmission line map (OSM, 2020) shown in Fig. 3B to represent the potential grid expansion with the ongoing construction of the Dasu and Diamer Basha hydropower projects in the upper Indus (The Nation, 2020). These transmission lines, which are currently under construction, are represented as they will be instrumental in bringing private 
Table 3

Proposed model parameters and cost components differentiated for three plant types. Values are determined in discussion with stakeholders unless specified otherwise.

\begin{tabular}{|c|c|c|c|c|}
\hline \multirow[t]{2}{*}{ Component } & & \multirow[t]{2}{*}{ River power plant } & \multicolumn{2}{|l|}{ Diversion Plant } \\
\hline & & & Large (>50 MW) & Small $(<50 \mathrm{MW})$ \\
\hline \multirow[t]{10}{*}{ Technical parameters } & Search location & Mainstream & & Tributary \\
\hline & Minimum head $(\mathrm{m})$ & $4-5 \mathrm{~m}$ & & $20 \mathrm{~m}$ \\
\hline & Minimum design discharge $(\mathrm{m})$ & $0.1 \mathrm{~m}^{3} / \mathrm{s}$ & & \\
\hline & Minimum distance between intake weir and powerhouse & - & $500 \mathrm{~m}$ & $500 \mathrm{~m}$ \\
\hline & $\begin{array}{l}\text { Search radius based on maximum distance between intake weir and power } \\
\text { house }\end{array}$ & - & 3 km (Vinca et al., 2019) & $1.5 \mathrm{~km}$ \\
\hline & Minimum distance between two power plants & $1 \mathrm{~km}$ & & $500 \mathrm{~m}$ \\
\hline & River segment length & $4 \mathrm{~km}$ & & $2 \mathrm{~km}$ \\
\hline & Design flow ( $\mathrm{QXX}=$ flow exceeded $\mathrm{xx} \%$ of the time) & Q50 & Q30 & Q90 \\
\hline & Generation efficiency & 70\% (Gernaat et al., 2017) & $80 \%$ (Zhou et al., 2015) & $70 \%$ \\
\hline & Transmission and distribution efficiency & $85 \%$ (NEPRA 2019) & & $96 \%$ \\
\hline \multirow[t]{17}{*}{ Capital cost components } & Blasted headrace tunnel & & $\checkmark$ & \\
\hline & De-sanding basin & & $\checkmark$ & $\checkmark$ \\
\hline & Steel penstock & $\checkmark$ & $\checkmark$ & $\checkmark$ \\
\hline & RCC Dam & $\checkmark$ & & \\
\hline & Fish passage & $\checkmark$ & $\checkmark$ & \\
\hline & Underground powerhouse & $\checkmark$ & $\checkmark$ & \\
\hline & Over-ground powerhouse & & & $\checkmark$ \\
\hline & Turbine & $\checkmark$ & $\checkmark$ & $\checkmark$ \\
\hline & Electro-technical equipment & $\checkmark$ & $\checkmark$ & $\checkmark$ \\
\hline & Miscellaneous mechanical equipment & $\checkmark$ & $\checkmark$ & \\
\hline & Road access & $\checkmark$ & $\checkmark$ & \\
\hline & Transmission line connection & On-grid & On-grid & Off-grid \\
\hline & Land acquisition (GoP, 1984) & Land value $+15 \%$ & Land value $+25 \%$ & - \\
\hline & Agricultural losses & $\checkmark$ & $\checkmark$ & \\
\hline & Loss of trees & 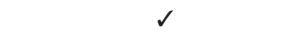 & $\checkmark$ & \\
\hline & Resettlement per capita & $3^{*} \mathrm{GDP}$ & & - \\
\hline & $\begin{array}{l}\text { Community compensation } \\
\text { (as \% of resettlement costs) }\end{array}$ & $10 \%$ & & - \\
\hline \multirow{5}{*}{$\begin{array}{l}\text { Other economic } \\
\text { parameters }\end{array}$} & Provincial Water Use charge (GoP, 1984) & PAK 0.425/kWh & & - \\
\hline & Discount rate & & & \\
\hline & Lifetime & $\begin{array}{l}40 \text { years (Gernaat et al., } \\
\text { 2017) }\end{array}$ & $\begin{array}{l}30 \text { years (Garegnani et al., } \\
\text { 2018) }\end{array}$ & $\begin{array}{l}15 \text { years (Kaldellis et al., 2005; Basso and Botter, } \\
\text { 2012) }\end{array}$ \\
\hline & $\begin{array}{l}\text { Owners cost due to long lead times } \\
\text { (as \% of capital investment) }\end{array}$ & 20\% (IRENA, 2012) & 10\% (IRENA, 2012) & - \\
\hline & $\begin{array}{l}\text { Operation \& maintenance } \\
\text { (as \% of capital investment) }\end{array}$ & 2\% (Gernaat et al., 2017) & $3 \%$ & $4 \%$ \\
\hline \multirow[t]{8}{*}{ Sustainability constrains } & Environmental flow requirement (as \% of annual average discharge) & $\begin{array}{l}\text { 30\% } \\
\text { (Gernaat et al., 2017; Moiz et }\end{array}$ & l., 2018 & - \\
\hline & $\begin{array}{l}\text { Landslide hazard } \\
\text { (as \% of capital investment) }\end{array}$ & $5 \%$ & $7 \%$ & - \\
\hline & $\begin{array}{l}\text { Seismic hazard } \\
\text { (as \% of capital investment) }\end{array}$ & $5 \%$ & $7 \%$ & - \\
\hline & Buffer around thrusts & $3 \mathrm{~km}$ (JICA and NEA, 2014) & & \\
\hline & Buffer around faults & $1 \mathrm{~km}$ (JICA and NEA, 2014) & & \\
\hline & Buffer for cultural heritages & 1 km (NWFP-EPA, 2004) & & \\
\hline & Buffer for natural heritages & 2 km (NWFP-EPA, 2004) & & \\
\hline & Disputed areas added cost (as \% of capital investment) & $1 \%$ & & \\
\hline
\end{tabular}



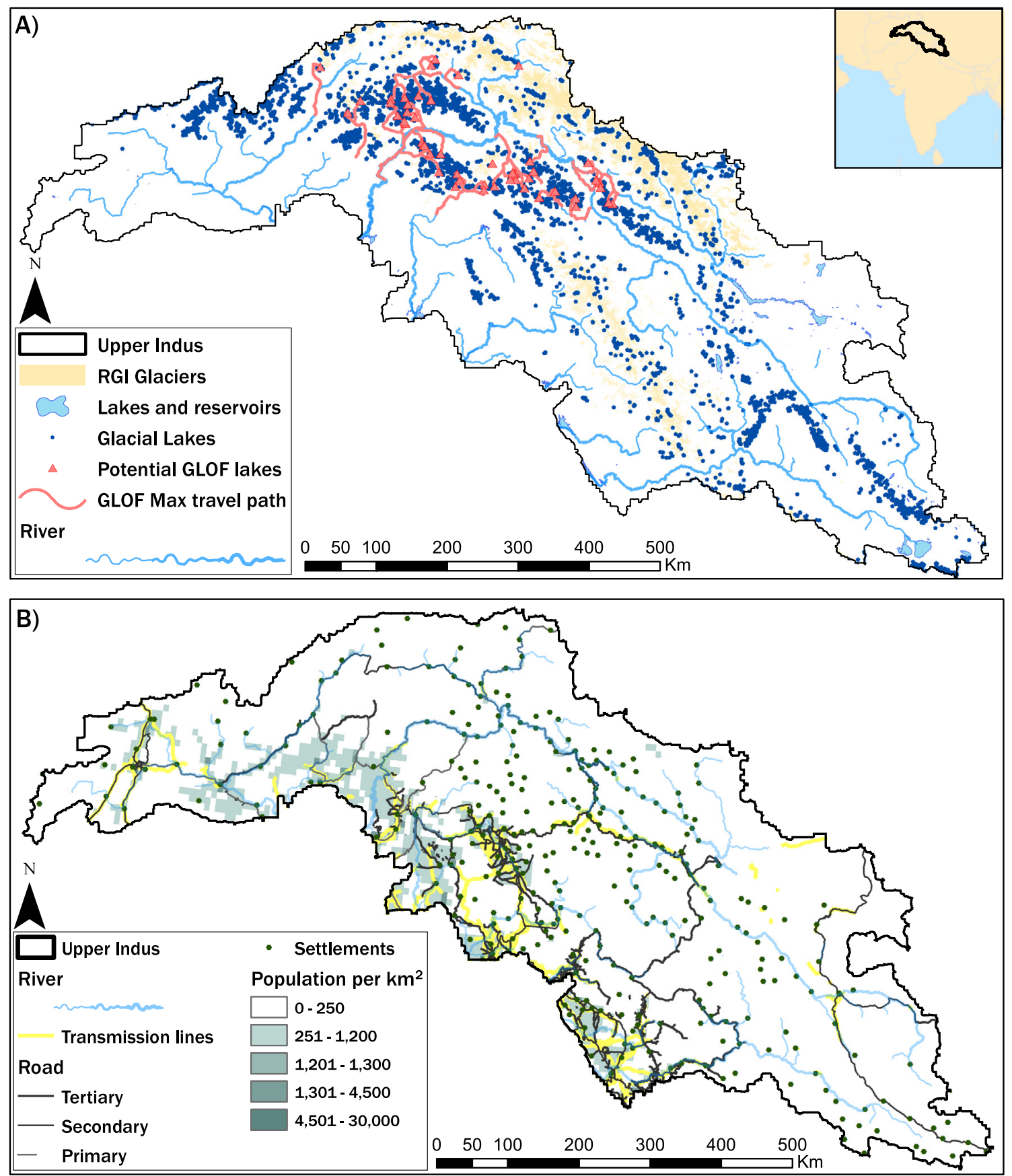

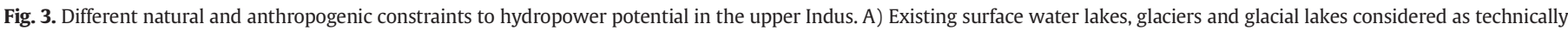

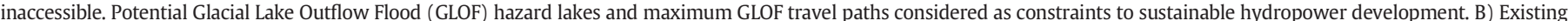

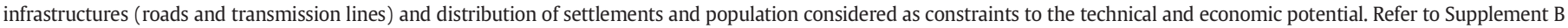
for data sources.

investments into the region. However, for small plants in the upper Indus, it will be most cost-effective to connect to a settlement as minigrid or off-grid systems (IRENA, 2012; Müller et al., 2016), similar to the majority of existing hydropower sites in the upper Indus (Siddiqi et al., 2012; Annandale, 2014). Settlement points from (ICIMOD, 2007) are used to identify the isolated communities beyond the urban areas in the southern part of the basin (Fig. 3B). For each grid cell, we thus evaluate the distance to nearest road, transmission line and settlement (Fig. 4A-C) and estimate associated costs.

Land acquisition by hydropower expansion, and associated population resettlement and land use loss, represent one of the most complex and uncertain aspects of hydropower costing (Garegnani et al., 2018; IRENA, 2020). To evaluate the land required for each hydropower project, for RP configuration we use reservoir area for a chosen dam height; for DP configuration we use twice the diversion pipes floor area evaluated as a product of the number, length, and diameter of the diversion pipes. Affected population in these land grid cells is extracted from the History Database of the Global Environment (HYDE) population density map (Klein Goldewijk et al., 2017) (Fig. 3B). Resettlement cost is applied at two scales. First, we estimate as per capita resettlement cost using the average compensation allocated to households affected by the Dasu project to obtain individual compensation. Second, we apply $10 \%$ of 

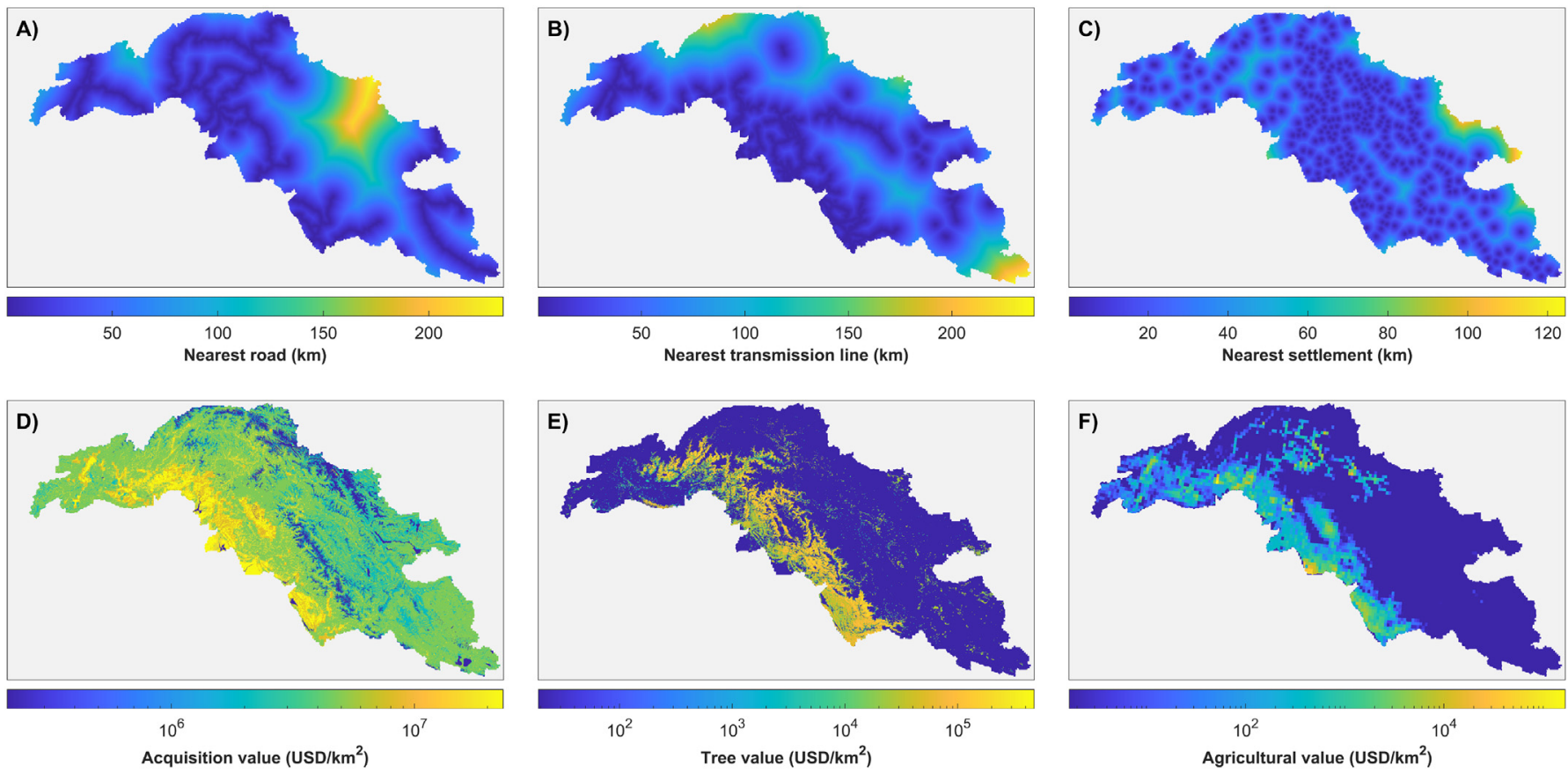

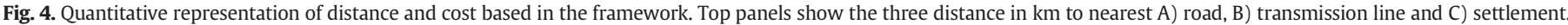
Bottom panels show land costs in USD $/ \mathrm{km}^{2}$ for D) acquisition value, E) tree value and $\mathrm{F}$ ) agricultural value.

the resettlement costs as community compensation, to represent the communal infrastructures or services provided by large projects under hydropower benefit sharing requirements.

For cost valuation of the land use losses caused by hydropower expansion, we follow the land acquisition act (1984) in Pakistan which requires compensation to be paid considering three factors: average land value in the preceding 3-5 years considering presence of buildings, the number of trees and standing crops that would be lost. An additional $15 \%$ or $25 \%$ surcharge is levied for land acquisition by public or private projects respectively. Land acquisition rates were available for basic classes of residential, cultivated, uncultivated and barren land for the Dasu project, each of which were subdivided into urban and rural (DHP, 2020b). We reclassify the 31 land use classes in a global land use map (ESA, 2016) into cultivated, uncultivated and barren classes. Additionally, all settlement point locations in ICIMOD (2007) are parsed as residential areas. Again, we use the HYDE population dataset (Klein Goldewijk et al., 2017) (Fig. 3B) to divide the basin into urban and rural cells. A population density of 250 people per $\mathrm{km}^{2}$ is selected as the threshold for the rural-urban divide, considering the population density of cells that are classified as urban area in the global land use map. We combine the developed land use map and a remote-sensing based tree density map (Crowther et al., 2015) with rates established for Dasu (DHP, 2020b; Upper Kohistan Forest Division, 2020) to evaluate gridded maps representing land acquisition value (Fig. 4D) and tree value (Fig. 4E) maps respectively.

Similarly, the value of standing crops is represented by an agricultural value map (Fig. 4F). We start with the latest high-resolution crop production maps simulated by the LPJmL hydrology and vegetation model set up for the Indus (Biemans et al., 2019; Smolenaars et al., 2021). The model specifically accounts for the double cropping in the Indus, distinguishes between rain-fed and irrigated production, and improves the representation of cryospheric contribution to agriculture. Annual crop production simulated for 13 crop classes are combined with the producer prices (FAO, 2021) for primary crops in India and Pakistan. Price data was not available for Afghanistan in (FAO, 2021). The seven crops classes representing specific crops (rice, maize, sunflower, soybean, groundnut, rapeseed, sugarcane) are mapped one-to- one with FAO producer prices. For the remaining six crop classes representing crop groups (temperate cereals, tropical cereals, pulses, temperate roots, tropical roots, others), crop prices are evaluated as the average of the prices available for major crop under each group, as summarized in Supplement F. Major crops under each group were identified from crop statistics report for Khyber Pakhtunkhwa (GoKP, 2020) and Gilgit-Baltistan (GoGB, 2020) provinces, which cover majority of the upper Indus. Both crop production and price data are taken as long-term annual averages over 2001-2010, though many crops prices are discontinuous. Thus, the agricultural value map is created as a sum of the average crop production scaled by the average crop prices. Essentially, the agricultural value maps explicitly represents the impact of hydropower expansion on areas currently used for food production.

The various assumptions for large RP, large DP and small DP (Table 3 ) are combined in a search algorithm that minimizes per unit production costs (Gernaat et al., 2017). First, outlets are generated in the mainstream and tributaries at specified river segment length. Second, for each outlet, possible inlet locations are identified within the allowed search radius. Third, the algorithm minimizes the unit production cost at the site to identify the optimal inlet and corresponding component sizes for the DP configuration. Fourth, at the same outlet, various alternatives for the RP configuration are evaluated and the optimal dam and corresponding component sizes are identified. Finally, based on minimization of basin scale unit production cost, the optimal configuration of DP or RP at all outlets is identified to remove any overlaps between the DP and RP.

The unit cost of production is the levelized cost of energy evaluated as a ratio of annualized cost and annual energy production. The total energy produced annually is evaluated for the two plant types using (Gernaat et al., 2017):

$P_{D P}=\rho g\left(H_{\text {in }}-H_{P S}-h_{f}\right) Q_{D P} \times L_{D P} \times \eta_{g, D P} \times \eta_{d, g r i d} * 8760 \mathrm{hr} / \mathbf{y r}$

$P_{\mathrm{RP}}=\rho g\left(\mathrm{H}_{1}-\mathrm{H}_{2}\right) \mathbf{Q}_{\mathrm{RP}} \times \mathrm{LF}_{\mathrm{RP}} \times \eta_{\mathrm{g}, \mathrm{RD}} \times \eta_{\mathrm{d}, \mathrm{grid}} * 8760 \mathrm{hr} / \mathrm{yr}$

where $\boldsymbol{H}_{\boldsymbol{i n}}$ is the elevation of the diversion inlet (m), $\boldsymbol{H}_{\boldsymbol{P S}}$ is the elevation of the power station ( $\mathrm{m}$ ) and $\boldsymbol{h}_{\boldsymbol{f}}$ is the head loss ( $\mathrm{m}$ ) in the diversion pipe 
from the inlet to power station for DP projects as in Gernaat et al. (2017). For RP projects, $\boldsymbol{H}_{\mathbf{1}}$ is headwater elevation equal to the damheight ( $\mathrm{m}$ ) and $\boldsymbol{H}_{\mathbf{2}}$ is tailwater elevation evaluated as a function of river depth and discharge. $\mathbf{Q} \boldsymbol{L F}$ and $\eta_{\mathbf{g}}$ are the design discharge, load factor and generation efficiencies for DP and RP plants while $\eta_{\mathbf{d}, \text { grid }}$ is the distribution efficiency differing for on or off-grid systems. The annualized cost of production is evaluated as a sum of all the technical and economic components represented for the three project types (Table 3). Owners cost and operation and maintenance costs are represented as percentages of capital costs. All costs are annualized over the defined economic lifetimes. We use Gernaat et al. (2017)'s threshold of unit production cost below USD $0.50 / \mathrm{kWh}$ for technical and USD $0.10 / \mathrm{kWh}$ for economic potential to identify a portfolio of optimal projects representing technical and economic potential. The USD $0.10 / \mathrm{kWh}$ cutoff matches the cost of thermal power in Pakistan which is the primary alternative to hydropower (DHP, 2019).

\subsection{Sustainable potential}

\subsubsection{Existing approaches}

Many non-economic and non-technical costs of hydropower remain underrepresented in potential estimation studies (Moran et al., 2018). The insufficiency of conventional potential estimation is highlighted by studies that develop ways to include other sustainability parameters to rank a set of hydropower projects (Annandale, 2014; Kao et al., 2014). Annandale (2014) incorporate rich ecological criteria to represent environmental impact and go beyond excluding protected areas from hydropower development. Rojanamon et al. (2009) incorporate community preferences in ranking of hydropower projects. JICA and NEA (2014) present the most comprehensive ranking using over 20 criteria representing hydrological, geological, financial, social, livelihood and environmental risks, developed in consultation with stakeholders. But, as Ray et al. (2018) and (IHA, 2020) argue, sustainability criteria such as climatic, geophysical, financial and socio-environmental risks should be incorporated into the sizing of individual projects itself. For instance, (Gernaat et al., 2017; Garegnani et al., 2018) demonstrate that the generated portfolio of hydropower projects varies when potential estimation is done by excluding water abstractions by other sectors. Similarly, (Vaidya et al., 2021) qualitatively explore factors that determine technical, environmental, financial and social sustainability for hydropower in South Asia and highlight the need for a quantitative approach that integrates these considerations into current hydropower decision making.

\subsubsection{Proposed approach}

Hydropower investments in the past were biased because projects gained momentum based on technical or economic assessments, and posterior performance rankings based on additional criteria were sidelined (WCD, 2000). For preventing such biases in hydropower decisions, known sustainability criteria should be integrated into potential estimation methods to generate a superior set of projects that weight technical, economical and sustainability criteria concurrently. Thus, we develop three ways to integrate factors that constrain the sustainability of hydropower into the technical and economic module developed in Section 3.2. First, we look at factors that constrain the water available for hydropower given the shared water uses under the WEF nexus. Second, we explore binary constraints that reduce the spatial areas available for hydropower. Third, we look at categorical constraints that represent an additional cost factor associated with acceptable risk management. We identify the non-technical and non-economic constraints relevant to the upper Indus from stakeholder inputs and literature and select suitable datasets to represent them. We then incorporate the constraints in either of the three ways for to establish the sustainable potential.

We re-assess design discharge input to Eqs.(3) and (4) in by considering factors that change water availability. First, the long-term monthly average water consumption for three sectors, namely - household, industry and agriculture estimated by Smolenaars et al. (2021), are subtracted from available runoff to get sustainable design discharge based on available discharges after water abstraction (Supplement G). Both SDG6 and SDG14 require preservation of aquatic biodiversity through release of environmental flows. However, federal policies in Pakistan do not decree a standard for environmental flow, except for requiring an environmental impact assessment for projects $>50 \mathrm{MW}$ or projects in an environmentally sensitive area. Hence, we apply an environmental flow requirement of $30 \%$ of the average annual discharge (Gernaat et al., 2017; Moiz et al., 2018). The change in discharge due to climate change is not considered a major risk by the stakeholders though projections suggest change in seasonal water availability (Wijngaard et al., 2017; Lutz et al., 2020). Especially for the private sector climate risks remain largely unaccounted (Dhaubanjar and Mufti, 2020) for as all hydrological risk is legally borne by the power purchaser (GoP, 2015). Nonetheless, we assess the potential impact of climate change on design flows and hydropower potential by forcing the upper Indus cryospheric-hydrological model with downscaled projections from CMIP6 general circulation models (GCMs) (Eyring et al., 2016) to simulate future hydrology.

We include earthquake and landslide risk in four steps. First, we exclude areas in proximity to tectonic thrust or fault lines (Mohadjer et al., 2016) that have a high likelihood to face impacts of both disasters (Schwanghart et al., 2018). Second, we remove areas with high seismic risk. Third, we apply a cost factor for land stabilization and seismic resistant structures in medium risk areas for both disaster types. Based on seismic zone definitions in national building codes (BIS, 2002; PEC, 2007) and global seismic risk definitions (Giardini et al., 2003) we define high, medium and low risk zones using peak ground acceleration (Fig. 5A). Similarly, for landslides, in the absence of scalable national definitions, we use a global dataset (Stanley and Kirschbaum, 2017) to define the three risk classes (Fig. 5B). We exclude these geo-hazard costs for small projects as stakeholders consider communities resilient and able to rebuild plant themselves after disasters. To a certain extent, the higher operation and maintenance cost used for the small plants is also intended to cover post-disaster recovery.

Alongside these geo-hazard considerations, we exclude protected natural heritage sites to align with SDG 15 . Natural heritages are taken from the World Database on Protected Areas (WDPA). Cultural heritages are identified from the UNESCO world heritage sites and the federally protected archaeological sites and monuments (GoP, 1997) (Fig. 5B). We include costs of fish passages in larger projects in lieu of cost associated with similar environmental protection measures. While small plants can have environmental costs (Annandale, 2014), we exempt them here considering that their impacts are fewer in comparison to large plants and potentially compensated by the reduction in biomass use due to rural electrification (Siddiqi et al., 2012). As indicated by stakeholders, we also levy additional administration costs for large projects in disputed areas of the upper Indus.

\subsection{Visualized and remaining potential}

Most studies estimate remaining potential as the difference between the estimated theoretical, technical or economic potental and the visualized potential. For the upper Indus, an up-to-date geo-referenced inventory of existing and planned hydropower projects in the basin is missing. Hence, the visualized potential needs to be estimated based on review and integration of global databases on dams and power plants as well as publicly available government datasets. Thereafter, areas with existing projects or dam reservoirs can be excluded and the proposed model rerun to estimate remaining potential under technical, economic and sustainable classes.

\section{Discussion}

Defining realistic goals is key to a successful implementation of the SDGs (Biermann et al., 2017). We developed a framework for optimal 

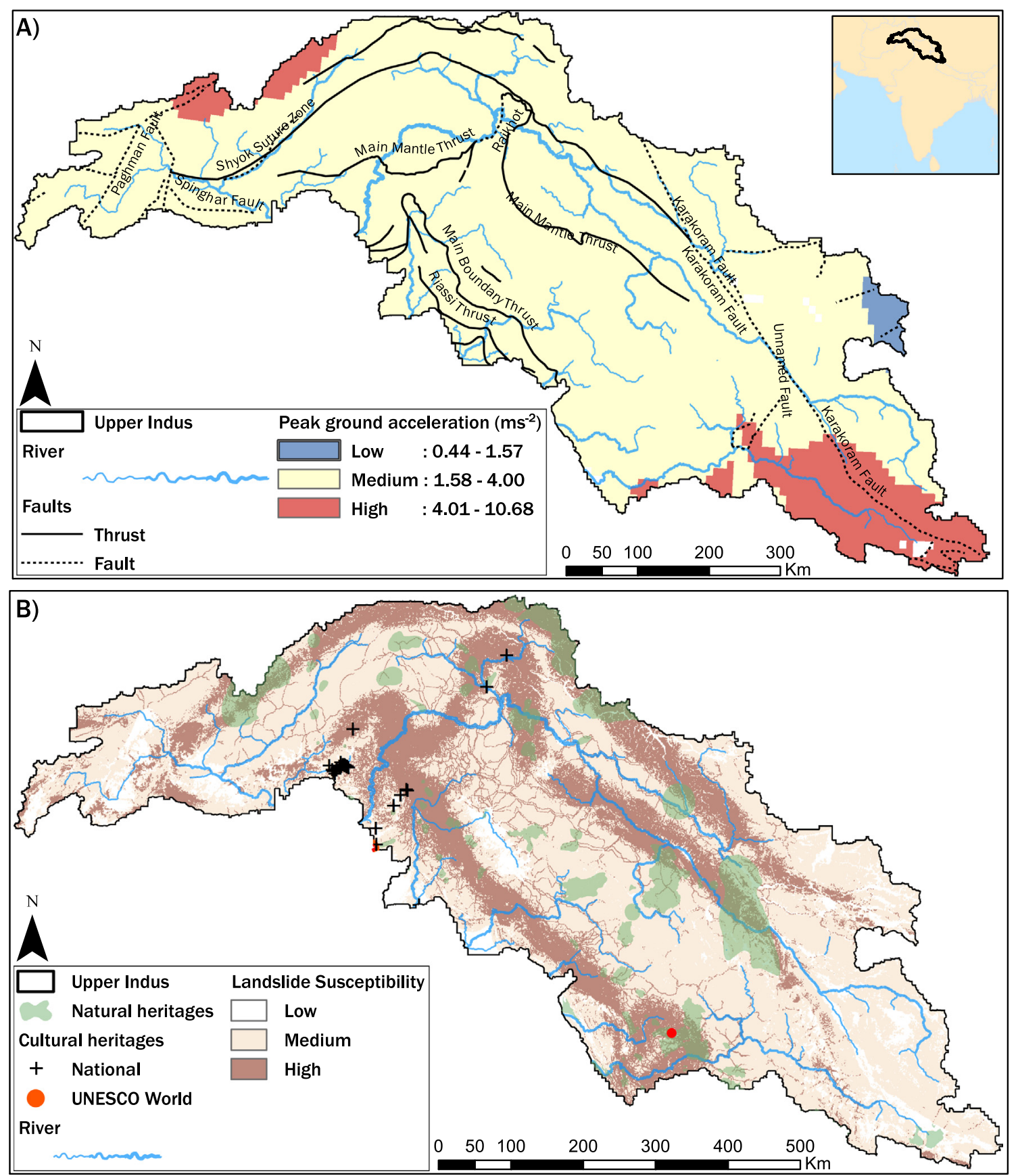

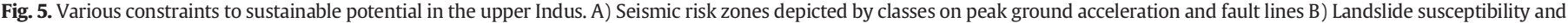
protected heritages (natural and cultural). Refer to Supplement B for data sources.

siting, sizing and configuring of hydropower plants to improve goal-setting and decision-making in hydropower by minimizing conflicts between SDGs. The stepwise estimation method for the four classes of potential established here shows that the classical theoretical potential can be misleading because it ignores many factors that will affect hydropower development and sustainability in the long run. The pitfalls of the current use of technical and economic potential as the basis for hydropower project screening is clearly demonstrated by the recent damages by glacial flooding in northeast India to a hydropower plant site selected with limited consideration for geo-hazards (Gupta et al., 2021). Adding more stringent sustainability criterions in the initial selection of hydropower plants can avoid such risks. To this end, we demonstrate that there are many quantifiable sustainability factors that can be incorporated from an early stage by systematically exploring the linkages between hydropower and other SDGs. Compared to traditional approaches, the sustainable hydropower potential class we define provides a stronger knowledgebase for realistic goal-setting. Subsequently, the development of hydropower will already exclude unsustainable projects in conflict with the WEF nexus and other SDG linkages. The approach provides a superior starting point for hydropower decisions; it breaks the existing siloed-approach and prevents past failures caused by the use of hydropower portfolios identified without consideration for sectors beyond energy.

The framework provides a quantitative basis to set sub-basin development plans. Sub-basins that have surplus hydropower should prioritize its development and energy trade. Energy-poor sub-basins should 
identify alternative energy sources to achieve energy security and focus its resources on other developments. The generated portfolio can be ranked further based on performance indicators not integrated into the framework. For instance, river fragmentation, considered another environmental impact of hydropower, can be evaluated using the degree of fragmentation or connectivity status indices (Grill et al., 2019). Similarly, the number of jobs created by hydropower projects can be estimated to assess local benefits (Frantzis, 2010). Stakeholders should be engaged to identify performance indicators of their interest and assess tradeoffs posed by different hydropower projects.

Though we develop this framework with a focus on run-of-river plants, the concept can be extended to consider other plant types by utilizing suitable cost functions for plant sizing and adding relevant sustainability criterions. Our framework could potentially include Fekete et al.'s (2010) approach for theoretical identification of storage hydropower plants; however, representation of indirect costs of storage plants should be expanded alongside. Canal based hydropower, an important resource in the Indus (Siddiqi et al., 2012) could be incorporated using Butera and Balestra (2015)'s approach if geo-referenced data on canal system and withdrawals are available. Even for the run-of-river plants, a detailed cost database for existing projects in the Indus could provide a basis to validate and improve the cost functions used here. Nevertheless, our method comes a long way to provide realistic first estimates for relative assessment of projects; on-site assessments to estimate absolute costs can then be conducted for a subset of promising projects.

Economic sizing of hydropower projects is also highly dependent on the local energy markets and tariff schemes (Kaldellis et al., 2005; Bøckman et al., 2008). For the private sector, design decisions often focus on maximizing profit; hence they may target demand areas with high tariff or hours with peak demand. Meanwhile in community run SHPs, projects are sized to meet total energy demands (Cuya et al., 2013; Müller et al., 2016). Such influences of demand on hydropower sizing are not included in this framework because we disaggregate our goal of evaluating sustainable hydropower development pathways for the Indus considering the WEF nexus linkages in the SDGs. The presented framework for identification of hydropower potential in the upper Indus subsequently provides the basis for future work where we explore how the estimated hydropower potential may be utilized given future trends in energy and water demands under the WEF nexus.

Many localized datasets can be added to reduce the uncertainties and enrich the framework for the Upper Indus. Cost functions used for project sizing here represent US and Norwegian industry practices. Development of Indus specific cost function through analysis of existing project prices as done by (Aggidis et al., 2010) for the UK would provide more realistic price estimates for the basin, which may be lower than those in western countries. A spatially explicit and rich demographic dataset could allow for a dynamic cost function to estimate the resettlement cost. With better demographic data, multiple socio-economic criteria can be used to characterize the population and extract corresponding compensation from an entitlement matrix (DHP, 2020a). Soil and lithology maps can further represent the technical stability of sites. Data on sediment loading in the river would allow for a direct representation of risks posed by sedimentation as done by Schmitt et al., (2018). Reliable snow avalanches risk datasets can allow for its addition.

Our framework builds on the premise that hydropower development and associated water and land resources management should consider the basin rather than the country perspective in transboundary basins like the Indus. The basin perspective is not only imperative to capture the long-term sustainability of water resources management, but it can also provide an entry point for transboundary co-operation to balance the priorities across the basin countries. However, the challenge lies with obtaining diverse data to characterize the variations and bottlenecks across the basins countries. Our generalization of hydropower practices in Pakistan to generate model parameters for all of upper Indus (Table 3) should be varied per basin country to represent the varying transboundary perspectives. Thus, future work should first engage with stakeholders from all basin countries to identify spatial variation. Second, mapping of stakeholder preferences should also include multi-disciplinary experts from across the water-energy-food-environment sectors. Third, stakeholders should also be consciously selected to represent development priorities at the community, province and central levels to capture the socio-cultural value of resource use for sustaining local livelihood and traditional practices versus larger national or basin-scale development. We found the iterative engagements with hydropower experts using the Delphi approach apt for getting specific information on hydropower design and policy requirement parameters (Table 3). However, teasing out sectorial trade-offs and interlinked sustainability perspectives was challenging in these single-sector discussions. Further criterions for sustainability should be identified from another round of face-to-face Delphi consultation actively engaging diverse stakeholders from beyond hydropower to negotiate their preferences for land and water resources management between hydropower and other usage across the basin countries.

More generally, for application to any basin - transboundary or otherwise - the relevancy of each factor considered in our framework should be reconsidered. The spatial layers considered and resolution chosen in our framework focus on the competing interests in the upper Indus. To generate high-resolution discharge, we use a coupled cryospheric-hydrological model that capture the dominant meltwater dynamics. Best estimates for discharge, and also crop production, should be obtained based on observed or modelled data that sufficiently characterize the study area. Stakeholder interactions should be used to identify key technical, economic, environmental, geo-hazard and social parameters to hydropower design and relevant datasets should be added, as done here. For example, high-resolution flood zone maps should be considered in basins more sensitive to floods than the upper Indus. Maps on ecosystem services and important aquatic biodiversity habitats can be added to consider river corridors that have high environmental or livelihoods value. For a basin that is more developed, cultivated or densely populated than the Upper Indus, higher resolution population and land use map may be necessary to accurately capture the resettlement and land acquisition costs. Other sectors interlinked with hydropower development should be identified and their implications should be translated into factors that affect available discharge, available areas or costs for hydropower development under the sustainable potential.

Nevertheless, our framework makes considerable advances in bridging the gap between large and small scale hydropower exploration. The high-resolution assessment method we develop enables the identification of plants of various sizes, in line with requirements put forward by stakeholders for the Upper Indus. The over 30 high-resolution datasets included clearly show there is strong spatial variation in the different factors affecting hydropower development. Our integration of multiple project types and various factors into hydropower potential assessment helps prevent biases in hydropower decision making. The sustainable hydropower potential increases the likelihood of fulfilling multiple SDGs concurrently not just at the central government or the whole basin level but also at the level of individual power developers as their starting point already considers the requirements of the multiple SDGs. In a broader context, our definition of "sustainable hydropower potential" formulated in adherence to the SDG concept is just a start. A concentrated effort is necessary to establish a standardized definition that gathers perspectives beyond the SDGs to both improve hydropower decision-making and motivate the development of localized datasets to support these exercises.

\section{Conclusions}

Target-setting for long-term hydropower development under SDG7 requires a thorough understanding of the spatial distribution of hydropower potential considering realistic system definitions, resource 
availabilities, emerging constraints and boundary conditions. To this end, we develop a systematic framework for assessment of sustainable hydropower potential that makes three folds improvements to existing methods. Namely, our framework selectively incorporates advances from emerging global and local multi-criteria assessments spanning various scales, explicitly represents local policies and preferences for hydropower development, and uses over 30 datasets to evaluate hydropower potential considering technical, economic and sustainability constraints to its realization in the Indus. The tiered framework is setup to first estimate theoretical potential, followed by an exploration of factors affecting hydropower, to quantify the technical and economic potential in the basin. Based on stakeholder inputs, the framework is designed with a differentiated approach for small and large hydropower plants of two run-of-river configurations to better represent the real-life variations in their implementations. Finally, we add on social, environmental, political, geo-hazard, and climate change related constraints to account for the WEF nexus and the SDG linkages and obtain a more realistic estimate termed the "sustainable hydropower potential". Such a science based knowledgebase is necessary for hydropower goal setting considering not only SDG7 (energy) but also the SDG2 (food), SDG6 (water), SDG9 (sustainable infrastructure), SDG13 (climate resilience), SDG14 (aquatic biodiversity) and SDG15 (terrestrial biodiversity). The framework can be applied to river basins beyond the Indus or expanded to different hydropower plant configurations, by systematically considering the various constraints that limit their development in discussion with key stakeholders. Future work will implement the proposed framework to set Indus-specific sustainable hydropower development goals and explore adaptation pathways to achieve the interlinked SDGs simultaneously.

Supplementary data to this article can be found online at https://doi. org/10.1016/j.scitotenv.2021.147142.

\section{CRediT authorship contribution statement}

Sanita Dhaubanjar: Conceptualization, Methodology, Software, Formal analysis, Data curation, Writing - original draft, Writing - review \& editing, Visualization, Project administration. Arthur Lutz: Conceptualization, Methodology, Formal analysis, Writing - review \& editing, Supervision, Project administration, Funding acquisition. David Gernaat: Conceptualization, Methodology, Software, Writing - review \& editing. Santosh Nepal: Conceptualization, Methodology, Data curation, Writing - review \& editing, Supervision, Project administration, Funding acquisition. Wouter Smolenaars: Conceptualization, Writing - review \& editing. Saurav Pradhananga: Conceptualization, Writing - review \& editing. Hester Biemans: Conceptualization, Writing - review \& editing, Funding acquisition. Fulco Ludwig: Conceptualization, Writing - review \& editing, Funding acquisition. Arun Shrestha: Conceptualization, Writing - review \& editing, Supervision, Project administration, Funding acquisition. Walter Immerzeel: Conceptualization, Methodology, Formal analysis, Writing - review \& editing, Supervision, Project administration, Funding acquisition.

\section{Declaration of competing interest}

The authors declare that they have no known competing financial interests or personal relationships that could have appeared to influence the work reported in this paper.

\section{Acknowledgements}

This research conducted under the SustaIndus project has received funding from the Netherlands Organisation for Scientific Research under WOTRO Joint Sustainable Development Goals (SDG) research program (Grant W 07.30318.002). This work was partially supported by Sustainable Development Investment Portfolio (SDIP), the Department of Foreign Affairs and Trade (DFAT), Government of Australia, the Swiss
Agency for Development and Cooperation (SDC) and by core funds from ICIMOD contributed by the governments of Afghanistan, Australia, Austria, Bangladesh, Bhutan, China, India, Myanmar, Nepal, Norway, Pakistan, Switzerland and the United Kingdom. The views and interpretations in this publication are those of the authors and are not necessarily attributable to their organizations. We are grateful to stakeholders Waqar Ahmed Khan, Meherban Khan, Muhammad Darjat, Muhammad Ziaullah, Ali Mehdi, and especially Asim Rauf Khan, for sharing their insights on hydropower production in Pakistan and providing feedback on model parameterization to represent the ground-realities. Samaa Mufti is acknowledged for coordinating the stakeholder discussions. Tim J Grandjean provided editorial comments on earlier version of the paper.

\section{References}

Abas, N., Khan, N., Saleem, M.S., Raza, M.H., 2019. Indus water treaty in the doldrums due to water-power Nexus. Eur J Secur Res 4, 201-242. https://doi.org/10.1007/s41125019-00043-y.

Afridi, Z.N., Afzal, J., Annandale, D., et al., 2014. Environmental Impact Assessment Handbook for Pakistan. IUCN Pakistan (National Impact Assessment Programme.

Aggidis, G.A., Luchinskaya, E., Rothschild, R., Howard, D.C., 2010. The costs of small-scale hydro power production: impact on the development of existing potential. Renew. Energy 35, 2632-2638. https://doi.org/10.1016/j.renene.2010.04.008.

AKRSP, 2020. Feasibility and Design Report of Construction of 300kW Madaklasht Mini Hydro Power Project in Tehsil Chitral and District Chitral (Khyber Pakhtunkhwa).

Annandale, D.D., Hagler Bailly Pakistan (Pvt) Ltd, 2014. Strategic Environmental Assessment for Hydropower in Azad Jammu and Kashmir. IUCN Pakistan, Islamabad.

Atlassian, 2018. Logistics capacity assessments: Afghanistan road network. https://dlca. logcluster.org/plugins/viewsource/viewpagesrc.action?pageId=4228552 (Accessed 2 Oct 2020).

Aziz, R., Ahmad, M.B., 2015. Pakistan's power crisis: the way forward. Special Report. 375. United States Institute of Peace (USIP).

Basso, S., Botter, G., 2012. Streamflow variability and optimal capacity of run-of-river hydropower plants. Water Resour. Res. 48. https://doi.org/10.1029/2012WR012017.

Biemans, H., Siderius, C., Lutz, A.F., et al., 2019. Importance of snow and glacier meltwater for agriculture on the Indo-Gangetic Plain. Nat Sustain 2, 594-601. https://doi.org/ 10.1038/s41893-019-0305-3.

Biermann, F., Kanie, N., Kim, R.E., 2017. Global governance by goal-setting: the novel approach of the UN sustainable development goals. Curr. Opin. Environ. Sustain. 26-27, 26-31.

BIS, 2002. Criteria for earthquake resistant design of structures. Part 1: General Provisions and Buildings. Bureau of Indian Standards, New Delhi.

Bøckman, T., Fleten, S.E., Juliussen, E., et al., 2008. Investment timing and optimal capacity choice for small hydropower projects. Eur. J. Oper. Res. 190, 255-267. https://doi.org/ 10.1016/j.ejor.2007.05.044.

Butera, I., Balestra, R., 2015. Estimation of the hydropower potential of irrigation networks. Renew. Sust. Energ. Rev. 48, 140-151.

Byers, L., Friedrich, J., Hennig, R., et al., 2019. Global Database of Power Plants (Washington, DC).

CEA, 2018. National Electricity Plan - Generation (New Delhi).

CEA (2019) Review of Performance of Hydro Power Stations 2018-19. (New Delhi).

Crowther, T.W., Glick, H.B., Covey, K.R., et al., 2015. Mapping tree density at a global scale. Nature 525, 201-205. https://doi.org/10.1038/nature14967.

Cuya, D.G.P., Brandimarte, L., Popescu, I., et al., 2013. A GIS-based assessment of maximum potential hydropower production in La Plata basin under global changes. Renew. Energy 50, 103-114. https://doi.org/10.1016/j.renene.2012.06.019.

Cyr, J.F., Landry, M., Gagnon, Y., 2011. Methodology for the large-scale assessment of small hydroelectric potential: application to the province of New Brunswick (Canada). Renew. Energy 36, 2940-2950. https://doi.org/10.1016/j.renene.2011.04.003.

de Souza Z, Tiago Filho, G.L., Barros, R.M., et al., 2017. The limit of sequential exploitation of a river's hydraulic potential. Renew. Sust. Energ. Rev. 68, 272-285. https://doi.org/ 10.1016/j.rser.2016.10.003.

Dhaubanjar, S., Mufti, S., 2020. Proceedings of SustaIndus Webinars on Hydropower Development Preferences and Practices in the Upper Indus Basin.

DHP, 2019. Economic benefit by avoided cost of alternative thermal power plants. Project Benefit and Analysis. Dasu Hydropower Project (DHP), pp. 72-77.

DHP, 2020a. Appendix-L social and resettlement management plan - compensation, rehabilitation and entitlements. Resettlement Action Plan. vol. 5.

DHP (2020b) Approved cost of land.

ESA, 2016. $300 \mathrm{~m}$ annual global land cover map from 2015 [dataset]. By European Space Agency (ESA). Clim. Chang. Initiat. - L. Cover Proj. http://maps.elie.ucl.ac.be/CCI/ viewer/download.php (Accessed 31 Aug 2016).

Eyring, V., Bony, S., Meehl, G.A., et al., 2016. Overview of the Coupled Model Intercomparison Project Phase 6 (CMIP6) experimental design and organization. Geosci. Model Dev. 9, 1937-1958. https://doi.org/10.5194/gmd-9-1937-2016.

FAO, 2014. AQUASTAT Geo-referenced Database on Dams - Southern Asia. http://www. fao.org/aquastat/en/databases/dams (Accessed 14 Sep 2020).

FAO, 2021. FAOSTAT Crop Producer Prices. http://www.fao.org/faostat/en/\#data/PP (Accessed 19 Mar 2021). 
Fekete, B.M., Wisser, D., Kroeze, C., et al., 2010. Millennium ecosystem assessment scenario drivers (1970-2050): climate and hydrological alterations. Glob. Biogeochem. Cycles 24, 1-12. https://doi.org/10.1029/2009gb003593.

Frantzis, L., 2010. Job Creation Opportunities in Hydropower Hydropower. National Hydropower Association Annual Conference. Navigant Consulting.

Fuso Nerini, F., Tomei, J., To, L.S., et al., 2018. Mapping synergies and trade-offs between energy and the sustainable development goals. Nat. Energy 3, 10-15. https://doi. org/10.1038/s41560-017-0036-5.

Garegnani, G., Sacchelli, S., Balest, J., Zambelli, P., 2018. GIS-based approach for assessing the energy potential and the financial feasibility of run-off-river hydro-power in Alpine valleys. Appl. Energy 216, 709-723. https://doi.org/ 10.1016/j.apenergy.2018.02.043

Gassert, F., Reig, P., Luo, T., Maddocks, A., 2013. Aqueduct Country and River Basin Rankings.

Gernaat, D.E.H.J., Bogaart, P.W., Vuuren, D.P.V., et al., 2017. High-resolution assessment of global technical and economic hydropower potential. Nat. Energy 2, 821-828. https://doi.org/10.1038/s41560-017-0006-y.

GFDRR, 2017. Afghanistan - Disaster Risk Profile. The World Bank, Washington, DC

Giardini, D., Grünthal, G., Shedlock, K.M., Zhang, P., 2003. The GSHAP global seismic Hazard map. In: Lee, W., Kanamori, H., Jennings, P., Kisslinger, C. (Eds.), International Handbook of Earthquake \& Engineering Seismology, International Geophysics Series 81 B. Academic Press, Amsterdam.

GoGB, 2020. Gilgit-Baltistan at a Glance 2020

GoGP Hydro Power Potential and Investment Prospects in Gilgit-Baltistan. Government of Gilgit-Baltistan, Gilgit-Baltistan, GoKP, 2016. Khyber Pakhtunkhwa Hydropower Policy. Government of Khyber Pakhtunkhwa, Pakistan.

GoKP, 2020. Crop Statistics Khyber Pakhtunkhwa 2018-2019.

GoP, 1984. The Land Acquisition Act. Government of Pakistan.

GoP, 1997. Guidelines for Sensitive and Critical Areas. Government of Pakistan.

GoP, 2014. Pakistan 2025: One nation-one vision (Islamabad).

GoP, 2015. Power generation policy 2015. Private Power and Infrastructure Board. Ministry of Water and Power. Government of Pakistan.

Grill, G., Lehner, B., Thieme, M., et al., 2019. Mapping the world's free-flowing rivers. Nature 569, 215-221. https://doi.org/10.1038/s41586-019-1111-9.

Gupta, J., Singh, V., Sarkar, S., 2021. Rishi Ganga: Clear Impact of Climate Change in Himalayan Disaster. Third Pole.

Haddad, O.B., Moradi-Jalal, M., Mariño, M.A., 2011. Design-operation optimisation of runof-river power plants. Proc Inst Civ Eng Water Manag 164, 463-475. https://doi.org/ 10.1680/wama.2011.164.9.463.

Hersbach, H., Bell, B., Berrisford, P., et al., 2020. The ERA5 global reanalysis. Q. J. R. Meteorol. Soc. 146, 1999-2049. https://doi.org/10.1002/qj.3803.

Hillman JE, Mccalpin M, Brock K (2020) The China-Pakistan economic corridor at five.

Hoes, O.A.C., Meijer, L.J.J., Van Der Ent, R.J., Van De Giesen, N.C., 2017. Systematic highresolution assessment of global hydropower potential. PLoS One 12. https://doi.org/ 10.1371/journal.pone.0171844.

Hsu, C.C., Sandford, B.A., 2007. The Delphi Technique: Making Sense of Consensus. Pract Assessment, Res Eval.

Hussain, A., Sarangi, G.K., Pandit, A., et al., 2019. Hydropower development in the Hindu Kush Himalayan region: issues, policies and opportunities. Renew. Sust. Energ. Rev. 446-461.

ICIMOD, 2007. Settlements of Hindu Kush Himalayan (HKH) Region. https://rds.icimod. org/home/datadetail?metadataid $=3752$ (Accessed 13 Nov 2020).

IHA, 2017. Hydropower Sector Climate Resilience Guide.

IHA, 2020. The Hydropower Sustainability Assessment Protocol.

IRENA, 2012. Hydropower. Renewable Energy Technologies: Cost analysis Series. 1.

IRENA, 2018. Renewable Power Generation Costs in 2018.

IRENA, 2020. Renewable Power Generation Costs in 2019.

JICA, NEA, 2014. Nationwide Master Plan Study on Storage-type Hydroelectric Power Development in Nepal: Strategic Environmental Impact Assessment Report.

Kalair, A.R., Abas, N., Ul Hasan, Q., et al., 2019. Water, energy and food nexus of Indus water treaty: water governance. Water-Energy Nexus 2, 10-24. https://doi.org/ 10.1016/j.wen.2019.04.001.

Kaldellis, J.K., Vlachou, D.S., Korbakis, G., 2005. Techno-economic evaluation of small hydro power plants in Greece: a complete sensitivity analysis. Energy Policy 33, 1969-1985. https://doi.org/10.1016/j.enpol.2004.03.018.

Kao S-C, McManamay RA, Stewart KM, et al (2014) New stream-reach development: a comprehensive assessment of hydropower energy potential in the United States.

Khan, W.A., 2018. Private sector hydropower development in Pakistan. Managing Shared Basins Series - Talk 26. LEAD Pakistan, Islamabad.

Khanal, S., Lutz, A.F., Kraaijenbrink, P.D.A., et al., 2020. Contrasting Response to Climate Change for Rivers Across High Mountain Asia (under review).

Khawaja, I., 2018. Vision 2025 score. Dawn.

Klein Goldewijk, K., Beusen, A., Doelman, J., Stehfest, E., 2017. Anthropogenic land use estimates for the Holocene - HYDE 3.2. Earth Syst. Sci. Data 9, 927-953. https://doi.org/ 10.5194/essd-9-927-2017.

Kusre, B.C., Baruah, D.C., Bordoloi, P.K., Patra, S.C., 2010. Assessment of hydropower potential using GIS and hydrological modeling technique in Kopili River basin in Assam (India). Appl. Energy 87, 298-309. https://doi.org/10.1016/j.apenergy.2009.07.019.

Labriet, M., Biberacher, M., Holden, P.B., et al., 2015. Assessing climate impacts on the energy sector with TIAM-WORLD: Focus on heating and cooling and hydropower potential. In: Giannakidis, G., Labriet, M., Gallachóir, Brian Ó., Tosato, G. (Eds.), Informing Energy and Climate Policies Using Energy Systems Models. Lecture Notes in Energy. Springer, pp. 389-409.

Larentis, D.G., Collischonn, W., Olivera, F., Tucci, C.E.M., 2010. Gis-based procedures for hydropower potential spotting. Energy 35, 4237-4243. https://doi.org/10.1016/j. energy.2010.07.014.
Lee, R., Brizzee, J., Cherry, S., Hall, D., 2007. Virtual hydropower prospecting: a foundation for water energy resource planning and development. J Map Geogr Libr 4, 336-347. https://doi.org/10.1080/15420350802142678.

Lehner, B., Czisch, G., Vassolo, S., 2005. The impact of global change on the hydropowe potential of Europe: a model-based analysis. Energy Policy 33, 839-855. https://doi. org/10.1016/j.enpol.2003.10.018.

Lehner, B., Liermann, C.R., Revenga, C., et al., 2011. High-resolution mapping of the world's reservoirs and dams for sustainable river-flow management. Front. Ecol. Environ. 9, 494-502. https://doi.org/10.1890/100125.

Lehner, B., Verdin, K., Jarvis, A., 2008. New Global Hydrography Derived From Spaceborne Elevation Data. EOS, Washington DC https://doi.org/10.1029/2008E0100001.

Lehner, B., Verdin, K., Jarvis, A., 2013. HydroSHEDS Technical Documentation Version 1.2. EOS Trans.

Lutz, A.F., Immerzeel, W.W., Kraaijenbrink, P.D.A., et al., 2016. Climate change impacts on the upper Indus hydrology: sources, shifts and extremes. PLoS One 11, e0165630. https://doi.org/10.1371/journal.pone.0165630.

Lutz, A.F., Immerzeel, W.W., Shrestha, A.B., Bierkens, M.F.P., 2014. Consistent increase in high Asia's runoff due to increasing glacier melt and precipitation. Nat. Clim. Chang. 4, 587-592. https://doi.org/10.1038/nclimate2237.

Lutz, A.F., Immerzeel, W.W., Siderius, C., et al., 2020. Assessing future shifts in the water supply sources of south Asian irrigated agriculture using a coupled high-resolution cryosphere-hydrology-crop model. In: Lutz, Arthur Friedrich, Immerzeel, Walter W., Siderius, Christian, et al. (Eds.), AGU Fall Meeting.

Lutz, A.F., ter Maat, H.W., Wijngaard, R.R., et al., 2019. South Asian river basins in a $1.5^{\circ} \mathrm{C}$ warmer world. Reg. Environ. Chang. 19, 833-847. https://doi.org/10.1007/s10113018-1433-4.

Mahar, S., Asher, M., 2020. Opinion: Himalayan hydropower is not a green alternative|The Third Pole. Third Pole https://www.thethirdpole.net/en/energy/opinion-himalayanhydropower-is-not-a-green-alternative/.

Maharjan, S.B., Mool, P.K., Lizong, W., et al., 2018. The Status of Glacial Lakes in the Hindu Kush Himalaya. ICIMOD Research Report 2018/1, Kathmandu.

Meijer, J.R., Huijbregts, M.A.J., Schotten, K.C.G.J., Schipper, A.M., 2018. Global patterns of current and future road infrastructure. Environ. Res. Lett. 13, 064006. https://doi. org/10.1088/1748-9326/aabd42.

Messager, M.L., Lehner, B., Grill, G., et al., 2016. Estimating the volume and age of water stored in global lakes using a geo-statistical approach. Nat. Commun. 7, 13603. https://doi.org/10.1038/ncomms13603.

Mirjat, N.H., Uqaili, M.A., Harijan, K., et al., 2017. A review of energy and power planning and policies of Pakistan. Renew. Sust. Energ. Rev. 79, 110-127.

Mishra, S., Singal, S.K., Khatod, D.K., 2011. Optimal installation of small hydropower plant - a review. Renew. Sust. Energ. Rev. 15, 3862-3869. https://doi.org/10.1016/j. rser.2011.07.008

Mohadjer, S., Alan Ehlers, T., Bendick, R., et al., 2016. A quaternary fault database for Central Asia. Nat. Hazards Earth Syst. Sci. 16, 529-542. https://doi.org/10.5194/nhess-16529-2016.

Moiz, A., Kawasaki, A., Koike, T., Shrestha, M., 2018. A systematic decision support tool for robust hydropower site selection in poorly gauged basins. Appl. Energy 224, 309-321. https://doi.org/10.1016/j.apenergy.2018.04.070.

Moran, E.F., Lopez, M.C., Moore, N., et al., 2018. Sustainable hydropower in the 21st century. Proc. Natl. Acad. Sci. 115, 11891-11898. https://doi.org/10.1073/ pnas.1809426115.

Müller, M.F., Thompson, S.E., Kelly, M.N., 2016. Bridging the information gap: a webGIS tool for rural electrification in data-scarce regions. Appl. Energy 171, 277-286. https://doi.org/10.1016/j.apenergy.2016.03.052.

NEPRA, 2005. The Grid Code.

NEPRA, 2009. Performance Standards (Generation) Rules 2009. National Electric Power Regulatory Authority, Islamabad, Pakistan.

NEPRA, 2018. Regulation of Generation, Transmission and Distribution of Electric Power National Electric Power Regulatory Authority, Pakistan.

NEPRA, 2019. State of the Industry 2019.

NTDC, 2019. Indicative Generation Capacity Expansion (IGCEP) Plan 2018-40 (Pakistan).

NVE, 2012a. Cost base for hydropower plants (with a generating capacity of more than 10,000 kW). In: Slapgård, J. (Ed.), Veileder 3. Norwegian Water Resources and Energy Directorate (NVE).

NVE, 2012b. Cost base for hydropower plants (with a generating capacity of up to 10000 kW). In: Slapgård, J. (Ed.), Veileder 2. Norwegian Water Resources and Energy Directorate (NVE), p. 182.

NWFP-EPA, 2004. Environmental assessment checklist. Water Reservoirs in Arid Zones. North-West Frontier Province Environmental Protection Agency, pp. 6-16.

Ogayar, B., Vidal, P.G., 2009. Cost determination of the electro-mechanical equipment of a small hydro-power plant. Renew. Energy 34, 6-13. https://doi.org/10.1016/j. renene.2008.04.039.

OpenStreetMap, 2020. HOTOSM Roads. https://data.humdata.org/dataset/hotosm_pak_ roads (accessed 3 Oct 2020)

Operacz, A., 2017. The term "effective hydropower potential" based on sustainable development - an initial case study of the Raba river in Poland. Renew. Sust. Energ. Rev. 75 , 1453-1463. https://doi.org/10.1016/j.rser.2016.11.141.

OSM, 2020. Powerlines Extracted Using OverpassTurbo. https://overpass-turbo.eu/ (accessed 15 Nov 2020).

Pandey, A., Lalrempuia, D., Jain, S.K., 2015. Assessment of hydropower potential using spatial technology and SWAT modelling in the Mat River, southern Mizoram, India. Hydrol. Sci. J. 60, 1651-1665. https://doi.org/10.1080/02626667.2014.943669.

PEC, 2007. Building code of Pakistan. Pakistan Engineering Council (PEC), Islamabad.

Pittock, J., Dumaresq, D., Bassi, A.M., 2016. Modeling the hydropower-food nexus in large river basins: a Mekong case study. Water (Switzerland) 8, 425. https://doi.org $10.3390 /$ w8100425. 
Pokhrel, Y.N., Oki, T., Kanae, S., 2008. A grid based assessment of global theoretical hydropower potential. Proc Hydraul Eng 52, 7-12. https://doi.org/10.2208/prohe.52.7.

PPIB, 2011. Hydropower Resources of Pakistan.

Punys, P., Dumbrauskas, A., Kvaraciejus, A., Vyciene, G., 2011. Tools for small hydropower plant resource planning and development: a review of technology and applications. Energies 4, 1258-1277.

Ramachandra, T.V., Shruthi, B.V., 2007. Spatial mapping of renewable energy potential. Renew. Sust. Energ. Rev. 11, 1460-1480.

Rasul, G., 2016. Managing the food, water, and energy Nexus for achieving the sustainable development goals in South Asia. Environ Dev 18, 1-12. https://doi.org/10.1016/j. envdev.2015.12.001.

Rasul, G., Neupane, N., Hussain, A., Pasakhala, B., 2019. Beyond hydropower: towards an integrated solution for water, energy and food security in South Asia. Int J Water Resour Dev. https://doi.org/10.1080/07900627.2019.1579705.

Ray, P.A., Bonzanigo, L., Wi, S., et al., 2018. Multidimensional stress test for hydropower investments facing climate, geophysical and financial uncertainty. Glob. Environ. Chang. 48, 168-181. https://doi.org/10.1016/j.gloenvcha.2017.11.013.

RGI Consortium, 2017. Randolph Glacier Inventory 6.0. http://www.glims.org/RGI/randolph60.html (accessed 1 Jul 2020).

Roach, T., Kapelan, Z., Ledbetter, R., 2015. Comparison of info-gap and robust optimisation methods for integrated water resource management under severe uncertainty. Procedia Eng 119, 874-883. https://doi.org/10.1016/j.proeng.2015.08.955.

Rojanamon, P., Chaisomphob, T., Bureekul, T., 2009. Application of geographical information system to site selection of small run-of-river hydropower project by considering engineering/economic/environmental criteria and social impact. Renew. Sust. Energ. Rev. 13, 2336-2348.

Samuelson, W., Zeckhauser, R., 1988. Status quo bias in decision making. J. Risk Uncertain. 1, 7-59. https://doi.org/10.1007/BF00055564.

Schmitt, R.J.P., Bizzi, S., Castelletti, A., Kondolf, G.M., 2018. Improved trade-offs of hydropower and sand connectivity by strategic dam planning in the Mekong. Nat Sustain 1. 96-104. https://doi.org/10.1038/s41893-018-0022-3.

Schwanghart, W., Ryan, M., Korup, O., 2018. Topographic and seismic constraints on the vulnerability of Himalayan hydropower. Geophys. Res. Lett. 45, 8985-8992. https:// doi.org/10.1029/2018GL079173.

SedAlp, 2015. WP6: interactions with structures. Sediment Management in Alpine Basins.

Siddiqi, A., Wescoat, J.L., Humair, S., Afridi, K., 2012. An empirical analysis of the hydropower portfolio in Pakistan. Energy Policy 50, 228-241. https://doi.org/10.1016/j. enpol.2012.06.063.

Singal, S.K., Saini, R.P., 2008. Analytical approach for development of correlations for cost of canal-based SHP schemes. Renew. Energy 33, 2549-2558. https://doi.org/10.1016/ j.renene.2008.02.010

Smolenaars, W., Lutz, A., Biemans, H., et al., 2020. From Narratives to Numbers; Spatial Downscaling and Quantification of Future Water-, Food- \& Energy- Security Requirements in the Indus Basin (Manuscript in submission).
Smolenaars W, Lutz AF, Jamil K, et al (2021) Spatio-temporal disaggregation of the impact of climate change and socio-economic development on upstream-downstream linkages in the Indus basin. (Manuscript in development).

Stanley, T., Kirschbaum, D.B., 2017. A heuristic approach to global landslide susceptibility mapping. Nat. Hazards 87, 145-164. https://doi.org/10.1007/s11069-017-2757-y.

Terink, W., Lutz, A.F., Simons, G.W.H., et al., 2015. SPHY v2.0: spatial processes in hydrology. Geosci. Model Dev. 8, 2009-2034. https://doi.org/10.5194/gmd-8-2009-2015.

The Nation, 2020. Imran Khan Orders Construction Work on Diamer Bhasha Dam. The Nation.

The World Bank, 2018. Fact Sheet: The Indus Waters Treaty 1960 and the World Bank. World Bank.

Upper Kohistan Forest Division, 2020. Rates of Forest and Wild Fruit Trees.

Vaidya, R., 2013. Water and hydropower in the green economy and sustainable development of the Hindu Kush-Himalayan region. Hydro Nepal J Water, Energy Environ 10, 11-19. https://doi.org/10.3126/hn.v10i0.7097.

Vaidya, R.A., Molden, D.J., Shrestha, A.B., et al., 2021. The role of hydropower in South Asia's energy future. Int J Water Resour Dev 37, 367-391. https://doi.org/10.1080/ 07900627.2021.1875809.

Vinca, A., Parkinson, S., Byers, E., et al., 2019. The Nexus solutions tTool (NEST): an open platform for optimizing multi-scale energy-water-land system transformations. Geosci. Model Dev. Discuss., 1-33 https://doi.org/10.5194/gmd-2019-134.

WAPDA, 2002. Policy for Power Generation Projects (Islamabad, Pakistan).

WAPDA, 2012. Hydro Potential in Pakistan.

WCD, 2000. Dams and Development: a New Framework for Decision-making. Earthscan Publications, London.

Wijngaard, R.R., Friedrich Lutz, A., Willem Immerzeel, W., et al., 2018. Climate change vs. socio-economic development: understanding the future south Asian water gap. Hydrol. Earth Syst. Sci. 22, 6297-6321. https://doi.org/10.5194/hess-22-6297-2018.

Wijngaard, R.R., Lutz, A.F., Nepal, S., et al., 2017. Future changes in hydro-climatic extremes in the upper Indus, Ganges, and Brahmaputra River basins. PLoS One 12, 1-26. https://doi.org/10.1371/journal.pone.0190224.

Yi, C.S., Lee, J.H., Shim, M.P., 2010. Site location analysis for small hydropower using geospatial information system. Renew. Energy 35, 852-861. https://doi.org/10.1016/j. renene.2009.08.003.

Yousuf, I., 2017. Optimally Locating the Small Hydro Units to Maximize Power Production under Uncertainty Flow, University of Engineering and Technology, Taxila, Pakistan.

Zaidi, A.Z., Khan, M., 2018. Identifying high potential locations for run-of-the-river hydroelectric power plants using GIS and digital elevation models. Renew. Sust. Energ. Rev. $89,106-116$

Zarfl, C., Lumsdon, A.E., Berlekamp, J., et al., 2015. A global boom in hydropower dam construction. Aquat. Sci. 77, 161-170. https://doi.org/10.1007/s00027-014-0377-0.

Zhou, Y., Hejazi, M., Smith, S., et al., 2015. A comprehensive view of global potential for hydro-generated electricity. Energy Environ. Sci. 8, 2622-2633. 